\title{
Fruit micromorphology of Siberian Apiaceae and its value for taxonomy of the family
}

\author{
T. A. Ostroumova \\ Botanical Garden of Biological Department of Lomonosov Moscow State University, Leninskie Gory, 1, build. 12, Moscow, \\ 119991, Russian Federation.E-mail: ostro_t_a@mail.ru; ORCID iD: https//orcid.org/0000-0002-7734-5133
}

Keywords: parallel variability, SEM, terminology, Umbelliferae.

Summary. Using a scanning electron microscope, the fruit micromorphology of the family Apiaceae of Siberia was studied. In total, the study covered 97 species of wild, adventive, and the most important cultivated plants. Within one fruit, micromorphology is heterogeneous; the most informative is the surface of the grooves and the rib bases. Exocarp cells are described (relative position, shape, size, nature of the boundaries between cells, outer walls, and fine relief of the cell wall). Characters most consistent within the species, for example, outgrowths on cell surface and a thin relief of cell wall, are noted. The characteristics of the ridges of the ribs, stomata (their presence, position on the surface of the fruit, and cuticle on the cells adjacent to the stomata), and epicuticular wax are also given. 25 species have hairs, scales, spines or warts on the surface; the shape of these structures and their fine relief are described. The importance of micromorphology for species identification and taxonomy is shown. The wide distribution of parallel variability in the family is noted.

\section{Микроморфология плода сибирских Аріасеае и ее значение для систематики семейства}

\author{
Т. А. Остроумова
}

Московский государственный университет им. М. В. Ломоносова, биологический факультет, Ботанический сад. Ленинские Горы, д. 1, стр. 12, г. Москва, 119991, Россия

Ключевые слова: зонтичные, параллельная изменчивость, СЭМ, терминология.

Аннотация. С применением сканирующего электронного микроскопа изучена микроморфология плодов 97 видов дикорастущих, заносных и основных культурных растений семейства Арiaceae Сибири. В пределах одного плода микроморфология неоднородна; наиболее информативна поверхность ложбинок и оснований ребер. Описаны клетки экзокарпа (взаимное расположение, форма, размеры, характер границ между клетками, наружные стенки, тонкий рельеф клеточной стенки). Отмечены признаки, которые наиболее константны в пределах вида, например, выросты на поверхности клеток и тонкий рельеф клеточной стенки. Дана также характеристика гребней ребер, устьиц (наличие, положение на поверхности плода, кутикула на прилегающих к устьицам клетках), эпикутикулярного воска. 25 видов имеют на поверхности волоски, чешуи, шипы или бородавки; описана форма этих структур и их тонкий рельеф. Показано значение микроморфологии для определения видов и систематики семейства. Отмечено широкое распространение параллельной изменчивости в семействе. 


\section{Introduction}

The study of the taxonomy of the family Apiaceae (Carrot family) faces considerable difficulties especially connected to the demarcation of genera in the subfamily Apioideae. As Plunkett et al. (2019) noted, the use of morphological and molecular methods does not yet allow for the creation of a satisfactory family system.

In the search for characters that are useful in taxonomy, the micromorphology of fruits is being studied; scanning electron microscopy data is becoming an important element in the description of new species (for example, Wang et al., 2013; Duran et al., 2015; Yildiri, Duman, 2017).

Examination of fruits at high magnification sometimes reveals traits that can later be discernible using a stereomicroscope at 20-40× magnification. For example, the species of Torilis Adans. differ in the shape of the glochidia apices (straight versus anchor-shaped), and large convex cells of the exocarp, characteristic of some genera of the family, create a shiny granular surface. We use this data in keys to identify species (Pimenov, Ostroumova, 2012; Plunkett et al., 2019). To establish the relationship of the food and medicinal plant of India, Seseli diffusum (Roxb. ex Sm.) Santapau et Wagh, the peculiar T-shaped hairs on the fruits played an important role (Pimenov et al., 2019, 2021).

Despite examples of the use of micromorphological characters in taxonomy, it is not enough known about the meaning of these characters. Many publications on micromorphology do not indicate the number of samples studied and do not mention intraspecific variability. We believe that the description of the fruit micromorphology of all species in a large region will make it possible to better assess the advantages and disadvantages of this method rather than using a small number of the most expressive examples. We follow the method of N. N. Kaden (1965), who tested his original fruit classification. He applied it to describe the fruits of all flowering plants in Central Russia, which made it possible to assess the scientific significance of his classification.

The micromorphology of the fruits of all the species of the Russian Apiaceae was studied. An analysis of the traits of species in the Russian Far East was recently published (Ostroumova, 2018), as well as illustrations of the micromorphological details of some species of Siberia (Kljuykov et al., 2016; Ostroumova, 2020). An atlas of fruits of the European part of Russia containing information on micromorphology has been published (Kljuykov et al., 2018).

Now we describe the micromorphology of all species of the Carrot family in Siberia; for each species, all character states found are listed. The assessment of the characters variability within the genera and species was carried out. Data are presented for 97 species of wild, adventive, and main cultivated plants including endemic ones: Bupleurum atargense, Bupleurum martjanovii. Aegopodium latifolium, and Peucedanum puberulum. The species belong to 54 genera including Bupleurum (10 species studied), Angelica (7), and Seseli (6).

\section{Material and methods}

The surface of some Siberian species has already been described in the article concerned with the Far East (Ostroumova, 2018):

Aegopodium alpestre Ledeb., Angelica anomala Avé-Lall., Angelica czernaevia (Fisch. et C. A. Mey.) Kitag., Angelica dahurica (Fisch. ex Hoffm.) Benth. et Hook. f., Angelica saxatilis Turcz., Anthriscus sylvestris (L.) Hoffm., Bupleurum longeradiatum Turcz., Bupleurum scorzonerifolium Willd., Bupleurum sibiricum Vest, Bupleurum triradiatum Adams ex Hoffm., Cicuta virosa L., Cnidium cnidiifolium (Turcz.) Schischk., Cnidium dauricum (Jacq.) Turcz. ex Fisch. et C. A. Mey., Cnidium monnieri (L.) Cusson ex Jussieu, Heracleum dissectum Ledeb., Kitagawia terebinthacea (Fisch. ex Trev.) Pimenov, Oenanthe javanica (Blume) DC., Osmorhiza aristata (Thunb.) Rydb., Ostericum tenuifolium (Pall. ex Spreng.) Chu YouChang, Ostericum viridiflorum (Turcz.) Kitag., Pachypleurum alpinum Ledeb., Phlojodicarpus sibiricus (Fisch. ex Spreng.) KosoPol., Phlojodicarpus villosus (Turcz. ex Fisch. et C. A. Mey.) Ledeb., Pimpinella thellungiana H. Wolff, Pleurospermum uralense Hoffm., Saposhnikovia divaricata (Turcz.) Schischk., Schulzia crinita (Pall.) Spreng., Seseli condensatum (L.) Rchb.f, Seseli seseloides (Fisch. et C. A. Mey. ex Turcz.) M. Hiroe, Sium suave Walter, Sphallerocarpus gracilis (Besser ex Trev.) KosoPol., Tilingia ajanensis Regel et Tiling.

The following samples were used to study the micromorphology of the remaining Siberian species. The material for the study was collected at the site of Apiaceae taxonomy in the Botanical Garden of M. V. Lomonosov Moscow State University (BG MSU), in the carpological collection of the Botanical Garden (CARP), obtained from the herbarium of 
MSU (Seregin, 2021. URL: https://plant.depo.msu. $\mathrm{ru} /$ ) and some other herbaria, acronyms according to Thiers (2008+. URL: http://sweetgum.nybg.org/ science/ih).

The origin of the material used in 2018 is not given here. The nomenclature follows the book "Umbelliferae of Russia" (Pimenov, Ostroumova, 2012). 97 species of Siberian flora were studied including alien and most popular cultivated plants.

Aegopodium latifolium Turcz.: "Irkutsk Region, $51^{\circ} 28^{\prime} 59^{\prime \prime} \mathrm{N}, 104^{\circ} 14^{\prime} 42^{\prime \prime}$ E. 7 VIII 2006. M. M. Ivanova" (IRK). "Irkutsk Region, $51^{\circ} 29^{\prime} 49^{\prime \prime} \mathrm{N}$, $104^{\circ} 14^{\prime} 31^{\prime \prime}$ E. 11 VII 2013. A. V. Verkhozina" (IRK).

Aegopodium podagraria $\mathrm{L}$. : BG MSU, wild.

Anethum graveolens L.: Fruits from market.

Angelica anomala Avé-Lall.: Additional specimens: "Primorye Territory. 16 VIII 1968. M. G. Pimenov, 161" (MHA). "Primorye Territory. 04 VIII 1978. T. I. Nechaeva" (MHA).

Angelica archangelica L.: BG MSU, 1994-018 (Moscow Region).

Angelica decurrens (Ledeb.) B. Fedtsch.: BG MSU 2004-020 (Altai Territory).

Angelica sylvestris L.: CARP, "E Kazakhstan, Altai Mts., Severnoe. 25 VIII 1972. M. G. Pimenov et al.".

Apium graveolens L.: MW0858859 (Kyrghyzstan).

Aulacospermum anomalum (Ledeb.) Ledeb.: BG MSU 1998-668 (Altai Territory).

Aulacospermum multifidum (Sm.) Meinsh CARP: "Chelyabinsk Region, Miass, 20 IX 1979. E. V. Kljuykov".

Bupleurum bicaule Helm: MW0106664 (Republic of Altai).

Bupleurum krylovianum Schischk.: MW0106570 (E Kazakhstan).

Bupleurum longifolium L. subsp. aureum (Fisch. ex Hoffm.) Soó: BG MSU, Taxonomic collection.

Bupleurum martjanovii Krylov: MW0106501 (Krasnoyarsk Territory, Sayan Mts.).

Bupleurum multinerve DC. CARP: "Altai Territory, $51^{\circ} 29^{\prime} \mathrm{N}, 83^{\circ} 18^{\prime}$ E. 24 VIII 2003. T. A. Ostroumova".

Bupleurum rotundifolium L.: MW0698649 (Republic of Georgia). MW0698666 (Azerbaijan). BG MSU 1989-740 (Republic of Crimea). CARP "Turkey, valley of Porsuk River. 08 IX 2008. M. G. Pimenov et al., 145".

Carum buriaticum Turcz.: BG MSU 2004-033 (Republic of Buryatia). MW0105882 (Republic of Buryatia). CARP "Republic of Buryatia, Podko- vochnaya Pad, 28 VIII 1998. M. G. Pimenov, E. V. Kljuykov".

Carum carvi L.: BG MSU 1974-451.

Caucalis platycarpos L.: BG MSU 1993-826 (Georgia); CARP: "Turkey, Bozdag Mts. 01 VII 2007. Pimenov and Kljuykov".

Cenolophium denudatum (Fisch. ex Hornem) Tutin: BS MSU 1976-456 (Ryazan Region).

Chaerophyllum prescottii DC.: CARP "Kazakhstan 18 VII 1977. M. E. Pimenova, 46". CARP "Kazakhstan, Tarbagatai Mts. 28 VIII 1979. E. V. Kljuykov".

Cnidium dauricum (Jacq.) Turcz. ex Fisch. et C. A. Mey.: "Primorye Territory. 10 IX 1965. V. N. Voroshilov, 12559" (MHA).

Cnidium monnieri (L.) Cusson ex Jussieu: "Primorye Territory. 13 IX 1960. I. A. Schreter, M. G. Pimenov" (MHA). "Khabarovsk Territory. 03 IX 1966. S. D. Schlothauer, 1074" (MHA). "Primorye Territory. 20 IX 1950. V. N. Voroshilov, 5018" (MHA).

Conioselinum longifolium Turcz.: "Republic of Buryatia. 18 VIII 1968. Ayanskaya et al.” (MHA).

Conioselinum tataricum Hoffm.: BG MSU 1974-262 (Kazakhstan).

Conium maculatum L.: CARP "Kazakhstan, Dzungarian Alatau Mts. 18 IX 1980. E. V. Kljuykov". CARP "Rostov Region. 17 VIII 2006. M. G. Pimenov".

Coriandrum sativum L.: Fruits from market.

Daucus carota L..: "Turkey. 10 VIII 2008 M. G. Pimenov et al." (MW).

Eryngium planum L.: CARP "Altai Territory, $51.49^{\circ} \mathrm{N}, 83.30^{\circ} \mathrm{E}$. 24 VIII 2003. T. A. Ostroumova”. BG MSU 2007-019 (Altai Territory). MW0107321 (E Kazakhstan).

Falcaria vulgaris Bernh.: CARP "Kazakhstan, Akmola reg., Astrakhanovka. 13 IX 1979. E. V. Kljuykov". MW0858918 (W Kazakhstan, Manghyshlak).

Ferula caspica M. Bieb.: CARP "Kazakhstan, Buran. 01 IX 1979. E. V. Kljuykov". CARP "E Kazakhstan, Kostanai reg., Sherubainura river. 21 VI 1991".

Ferula soongarica Pall. ex Spreng.: BG MSU 1989-670 (Altai Territory).

Ferula tatarica Fisch. ex Spreng.: CARP "Voronezh Region 1977. M. G. Pimenov et al.". "W Kazakhstan, Bokey Orda District. 16 VIII 1952. G. N. Nepli 428" (MHA). "Bashkortostan. 10 VIII 1980. E. E. Gogina and A. E. Matsenko" (MHA).

Ferulopsis hystrix (Bunge) Pimenov: CARP "Republic of Altai, 10 VIII 1990. M. G. Pimenov et 
M. G.Vasilieva, 124". CARP "Irkutsk Region. $53^{\circ} 24^{\prime} \mathrm{N}, 107^{\circ} 25^{\prime}$ E. 31 VII 2018. A. D. Dubrovskaya".

Haloselinum falcaria (Turcz.) Pimenov: CARP "Altai Republic. 10 VIII 1990. M. G. Pimenov and M. G. Vasilieva, 104". "Altai Rep., Chuyskaya steppe. 18 VIII 1962. V. Kuvaev, 205-5" (VILR).

Hansenia mongolica Turcz.: BG MSU 1992005 (Republic of Buryatia); MW0118690 (Republic of Buryatia).

Heracleum sibiricum L.: CARP "Kostroma Region. 22 VII 2012. U. A. Ukrainskaya".

Kadenia dubia (Schkuhr) Lavrova et V. N. Tikhom.: BG MSU 2004-012 (Altai Territory); CARP "E Kazakhstan. 04 IX 1979. E. V. Kljuykov, $366 "$.

Kadenia salina (Turcz.) Lavrova et V. N. Tikhom.: CARP "Republic of Buryatia. 28 VII 2003. M. G. Pimenov".

Kitagawia baicalensis (Redow. ex Willd.) Pimenov: CARP "Novosibirsk Region. 31 VIII 1972. Pimenov et al." BG MSU 2019-026 (Irkutsk Region).

Kitagawia terebinthacea (Fisch. ex Trev.) Pimenov: "Primorye Territory, 11 IX 1965. V. N. Voroshilov, 12566" (MHA) - as Peucedanum formosanum.

Lithosciadium multicaule Turcz.: "Herb. Meyer, Cult. in Hb. Petrop. 1839” (LE). MW0118857 (Republic of Buryatia).

Oenanthe aquatica (L.) Poir: MW0456810 (Tver Region).

Oenanthe javanica (Blume) DC.: "Sakhalin Region. 08 X 1967. A. K. Skvortsov" (MHA).

Ostericum palustre (Besser) Besser: BG MSU 1993-012 (Republic of Mordovia).

Ostericum tenuifolium (Pall. ex Spreng.) Chu YakChang: "Republic of Altai. 05 IX 1994. A. I. Shmakov et al." (ALTB). "Republic of Tuva. 28 VIII 1999. A. I. Shmakov et al." (ALTB).

Palimbia turgaica Lipsky ex Woronow: "W Kazakhstan, Kushum river" (LE).

Pastinaca sativa L.: BG MSU 2005-069 (from market).

Petroselinum crispum (Mill.) Fuss: Fruits from market.

Peucedanum morisonii Besser ex Schult.: CARP “Altai Territory, $83^{\circ} 03^{\prime} \mathrm{N}, 51^{\circ} 21^{\prime} \mathrm{E} .23$ VIII 2003. T. A. Ostroumova". CARP "Altai Territory. 12 IX 1989. M. G. Pimenov".

Peucedanum puberulum (Turcz.) Schischk.: "Baical. 25 VIII 1951. Popov et Bardunov" (LE). [Russia], "Dahuria 1831. Turcz." (LE). "Republic of Sakha. 25 VIII 1925. V. Drobov, A. Tarabunin” (LE).
Peucedanum vaginatum Ledeb.: CARP "Republic of Altai, Uluta 09 VIII 1990. M. G. Pimenov, M. G. Vasilieva". MW0117208 (Republic of Khakassia).

Phlojodicarpus sibiricus (Fisch. ex Spreng.) Koso-Pol.: CARP "Republic of Buryatia. 23 VIII 2003. M. G. Pimenov".

Phlojodicarpus villosus (Turcz. ex Fisch. et C. A. Mey.) Ledeb.: "W Chukchi Peninsula. 13 VIII 1958. Levichev et al." (LE).

Pimpinella saxifraga L.: MW0699473 (Azerbaijan). "Kaluga Region. 21 VIII 1987. V. D. Bochkin" (MHA).

Pimpinella thellungiana $\mathrm{H}$. Wolff: "Primorye Territory, M. Schischkin, 2578" (VLA).

Prangos pubescens (Pall. ex Spreng.) Pimenov et Kljuykov: "E Kazakhstan, the mouth of Bukon river. 15 VI 1863. Potanin, 211" (LE). [Russia] "Altai. 30 VI 2006. A. N. Kupriyanov et al." (KUZ). CARP "Kazakhstan, Zaisan depression. 30 VII 1972. M. G. Pimenov et al., 259". "Kazakhstan. 17 VII 1972. Stepanova" (AA).

Sajanella monstrosa (Willd. ex Spreng.) Soják: MW0105512 (E Kazakhstan). "Republic of Tuva. 10 VIII 1980. M. Danilov, P. Ens, 132" (MHA). "Republic of Tuva. 17 VIII 1979. V. Khanminchun et al." (MHA).

Sanicula europaea L. CARP Fruit from JB Caen 98-298. CARP "Republic of Abkhasia., Gagra. 2019".

Sanicula giraldii H. Wolff: MW "China. 13 IX 1998. Pimenov et al., 120".

Selinum carvifolia (L.) L.: MW0457690 (Tambov Region). MW0457694 (Kursk Region). MW0457701 (Nizhniy Novgorod Region).

Seseli buchtormense (Spreng.) W. D. J. Koch: CARP "Altai Territory. 24 VIII 2003. T. A Ostroumova".

Seseli ledebourii G. Don: CARP "E Kazakhstan. 06 IX 1979. E. V. Kljuykov". "Altai Territory. 28 VII 1998. Zhogol and Khrustaleva" (ALTB).

Seseli libanotis (L.) W. D. J. Koch: CARP "Tula Region. 04 VIII 1999. T. A. Ostroumova".

Seseli strictum Ledeb.: CARP "Altai Territory, Kolyvanskoye lake. 25 VIII 2003. T.A. Ostroumova”. CARP “Altai Territory, Zmeinogorsk. 30 VIII 1972. Pimenov et al." MW0860921 (E Kazakhstan).

Silaum silaus (L.) Schinz et Thell.: BG MSU 1974-298 (Republic of Moldova); MW0105089 (Kurgan Region).

Sium latifolium L.: MW0455875 (Voronezh Region). MW0455759 (Vladimir Region).

Sium sisaroideum DC.: BG MSU 1993-001. MW0105612 (E Kazakhstan). 
Stenocoelium athamantoides (M. Bieb.) Ledeb.: CARP "Republic of Altai, Sukhor Mt. 02 VIII 1990. M. G. Pimenov, M. G. Vasilieva". "Kazakhstan, Saur Mountain Ridge. 28 VII 1914. Senyushkin" (TK). "Republic of Altai, Aksai River. 23 VIII 1931. B. Shishkin and L. Chilkina" (LE). MW0105202 (Republic of Altai). "Republic of Altai. 16 VII 1995. Kamelin et al." (ALTB). "Republic of Altai. 11 VII 1992. Kamelin et al.” (ALTB).

Thysselinum palustre (L.) Hoffm.: "Tver Region, Sukholom. 07 XI 1974. E. V. Kljuykov" (MW). BG MSIU 1999-018 (Hort. Bot. Oulu - Finland, prov. Oulu, Kuivasjari). MW0117187 (Omsk Region).

Trinia ramosissima Ledeb.: MW0858689 (E Kazakhstan). CARP "25 VI 1973. A. A. Yanchenko".

Turgenia latifolia (L.) Hoffm.: BG MSU 1987224 (Kazakhstan).

Vicatia atrosanguinea (Kar. et Kir.) P. K. Mukh. et Pimenov: BG MSU 1989-013 (Kyrgyzstan).

Xanthoselinum alsaticum (L.) Schur: CARP "Rostov Region, 4047'N, 40²6'E. 19 VIII 2006. M. G. Pimenov".

SEM studies of fruits were made with a CamScan S-2 or Tescan Vega TS5130MM (CamScan MV 2300 ), accelerating voltage $15-20 \mathrm{kV}$ and working distance up to $56 \mathrm{~mm}$, at the magnification of 13 $3000 \times$. Dry fruits were placed on aluminium stubs and sputter-coated with gold or gold-palladium by Eiko IB-3 or S150A Sputter Coater to a thickness of ca. $25 \mathrm{~nm}$. The same area of the fruit was shot at different magnifications, which makes it possible to describe different surface details.

A certain difficulty in describing microsculptures is connected with the large range of magnifications obtained using SEM and the similarity of the sculptural elements visible at different magnifications. In this regard, the approach of Barthlott (1981) was found to be very useful, which identified three structural levels of the surface in botanical objects: cell shape (primary sculpture), fine relief of the cell wall (secondary sculpture), and epicuticular secretions (tertiary sculpture). In our previous publications (Ostroumova et al., 2010, 2011) the dictionary for characters and character states for the Umbelliferous fruits was compiled. Basic points for description of SEM images were published by Barthlot et Ehler (1977), Barthlot (1981), and Barthlot et al. (1998); for the fine relief of the cell wall, palynological terminology was used where possible (Hesse et al., 2009). In the fruits of the Siberian Apiaceae, several groups of characters were described (Table 1):

Indumentum. $\mathrm{a}$-glabrous (Fig. 1A-F); $\mathrm{b}$ - with simple hairs (Fig. 1G-I); c - multicellular spines and bristles (Fig. 1J-L, 2A, B); d-scales (Fig. 1M, $\mathrm{N})$; e - multicellular tubercles (Fig. 1O).

Ridges of dorsal ribs. a - as valleculas; b surface longitudinally sulcate, cell borders indistinct (Fig. 3A, lower right corner); c - oblong cells in longitudinal rows (Fig. 3B); $\mathrm{d}-$ isodiametric cells in longitudinal rows (Fig. 3C); e-smooth (Fig. 3D).

The size of exocarp cells. a - small $<35 \mu \mathrm{m}$ diam. (Fig. 3G, H), oblong cells $<35 \mu \mathrm{m}$ broad; $\mathrm{b}-$ large $>35 \mu \mathrm{m}$ diam. (Fig. 1D, E, 3I). To determine the cell size, not only SEM data were used but also data from previous anatomical studies.

Visibility of cell borders. a - distinct; b indistinct. We regarded cell borders as distinct when we could find an area of 20 or more cells with conspicuous borders.

Surface pattern if cell borders are indistinct. a smooth (Fig. 4A); b - longitudinally sulcate (with long regularly spaced grooves); c - longitudinally rugate, rugae $10-50 \mu \mathrm{m}$ long (Fig. 4B); $\mathrm{d}-$ irregularly rugate (Fig. 4C), e - foveate-tuberculate (Fig. 4D); f - undulate (Fig. 4E); g - with flattened projections (Fig. 4F); $\mathrm{h}$ - with acute projections (Fig. 4G); i - with dome-like projections Fig. 4H); $\mathrm{j}$ - papillose (cylindrical papillae); $\mathrm{k}$ - with short capitate papillae (Fig. 4I).

Cell arrangement. a - at random (Fig. 5A, B, F); b - in longitudinal rows (Fig. 5C-E).

Cell outlines. a - isodiametric (Fig. 5A, B); b oblong (length: width $>1.5$ ) - (Fig. 5C-E).

Cell border shape. a - raised (Fig. 5A, D, E); b sunken (Fig. 5B, C, F).

Curvature of outer periclinal walls. a - concave (Fig. 8F); b - flat (Fig. 6A, B); c - convex (Fig. 6C); $\mathrm{d}$-domed (Fig. 6D); e - with cylindrical papillae that are much narrower than epidermal cells (Fig. $1 \mathrm{M}, \mathrm{N}, 9 \mathrm{D}$ ); f - with flattened projections (Fig. 6E, F); g - with acute projections (Fig. 6G, 9D); h - with small hemispherical projections (Fig. $6 \mathrm{H}$ ).

Fine relief of outer walls (cuticular foldings). a cell wall invisible under thick wax layer (Fig. 7A); b-smooth (Fig. 8F); c-sparsely striate (Fig. 7B); d - striate, ridges $1-1.5 \mu \mathrm{m}$ broad (7CD); e - coarsely striate, ridges ca. $3 \mu \mathrm{m}$ (Fig. 7E); f - sparsely rugulate (Fig. 1E, 7F); g - rugulate (Fig. 7G); hrugulato-tuberculate (Fig. 2C); i - tuberculate; jstriate-knotted (Fig. 7H).

Number of stomata. a - stomata inconspicuous; $\mathrm{b}-1-3$ per 1 square $\mathrm{mm} ; \mathrm{c}->3$.

Level of stomata. a - at the exocarp level (Fig. $8 \mathrm{~A}, \mathrm{~B}) ; \mathrm{b}-$ on the bulges (Fig. 6D). 
Cuticle around stomata. a - usual (Fig. 8A, B); $\mathrm{b}-$ striate radiating (Fig. 8C).
Epicuticular secretions ("wax"). a - absent or a thin film that does not mask wall surface (Fig. 8D);
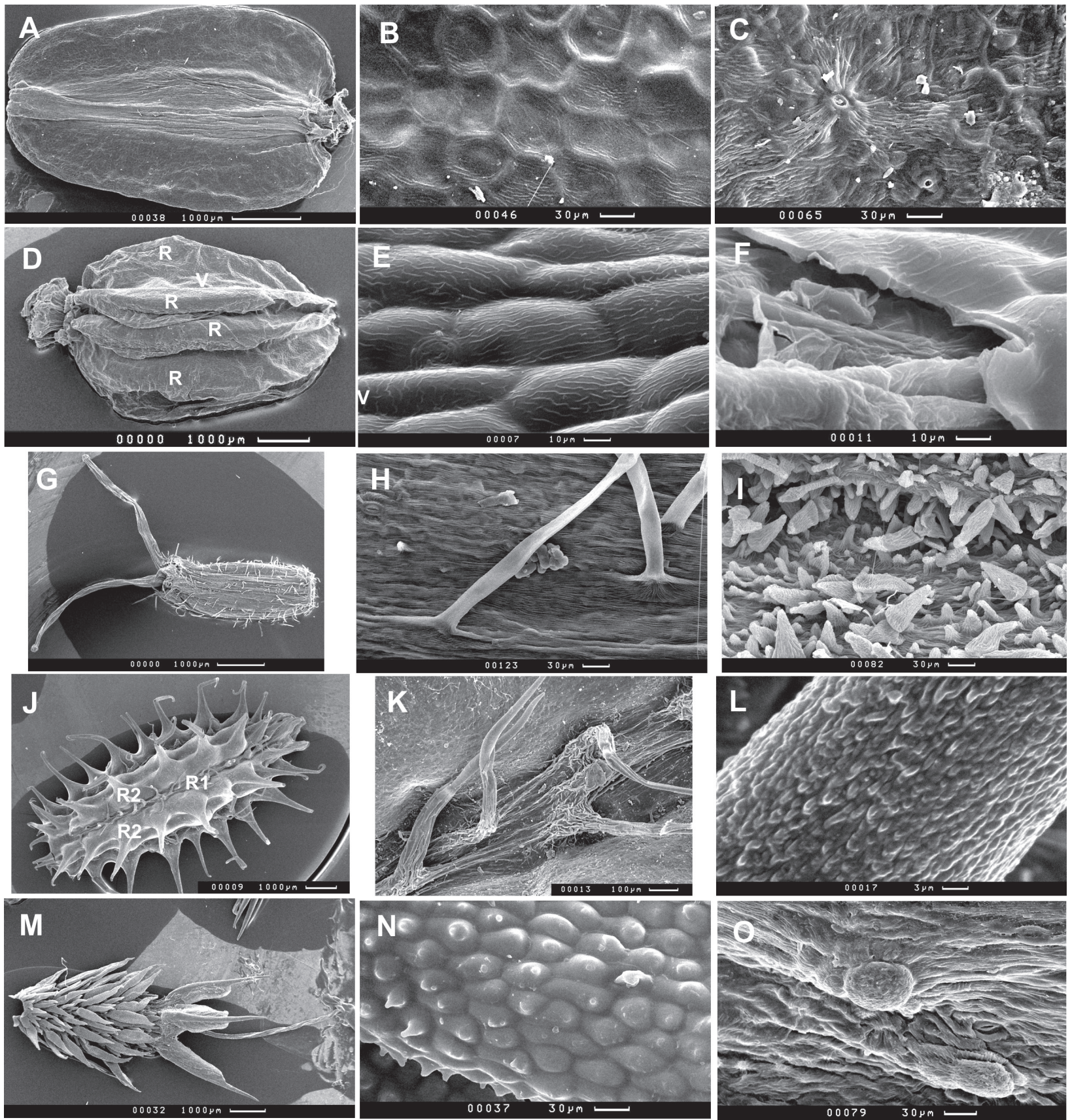

Fig. 1. Indumentum of fruits. A, B, C-Haloselinum falcaria. A - glabrous fruit with winged marginal ribs. B - wing surface, large isodaimetric cells with raised borders, flat outer periclinal walls, and rugulate fine relief. C - a stoma with striate radiating cuticle. D, E, F - Hansenia mongolica. D - glabrous mericarp with five winged ribs $(\mathrm{R}$ - rib, $\mathrm{V}$ - vallecula). E - large cells with sunken borders, convex outer periclinal wall and sparse-rugulate fine relief. F broken exocarp, thickness of outer walls is visible. G, H - Sajanella monstrosa. G - fruit with simple hairs and long styles. $\mathrm{H}$ - ribbon-like hairs with striate and sparsely rugulate surface; cell borders on the fruit surface indistinct, fruit surface undulate, fine relief striate. I - Seseli ledebouri, numerous simple hairs with rugulate surface and acute projections with striate-knotted surface. J, K, L - Caucalis platycarpos. J - fruit with multicellular hooked spines on four secondary ribs (R1 - primary rib, R2 - secondary rib). K - multicellular bristles with large apical cells on primary rib. L - tuberculate surface of the apical cell. M, N - Eryngium planum. M - a mericarp with three large calyx teeth and numerous scales of the fruit surface. $\mathrm{N}$ - scale surface, cell borders sunken, outer periclinal walls convex, domed, with acute projections and papillae, fine relief smooth. O - Saposhnikobia divaricata, tubercles with large apical cell and rugulate fine relief. 

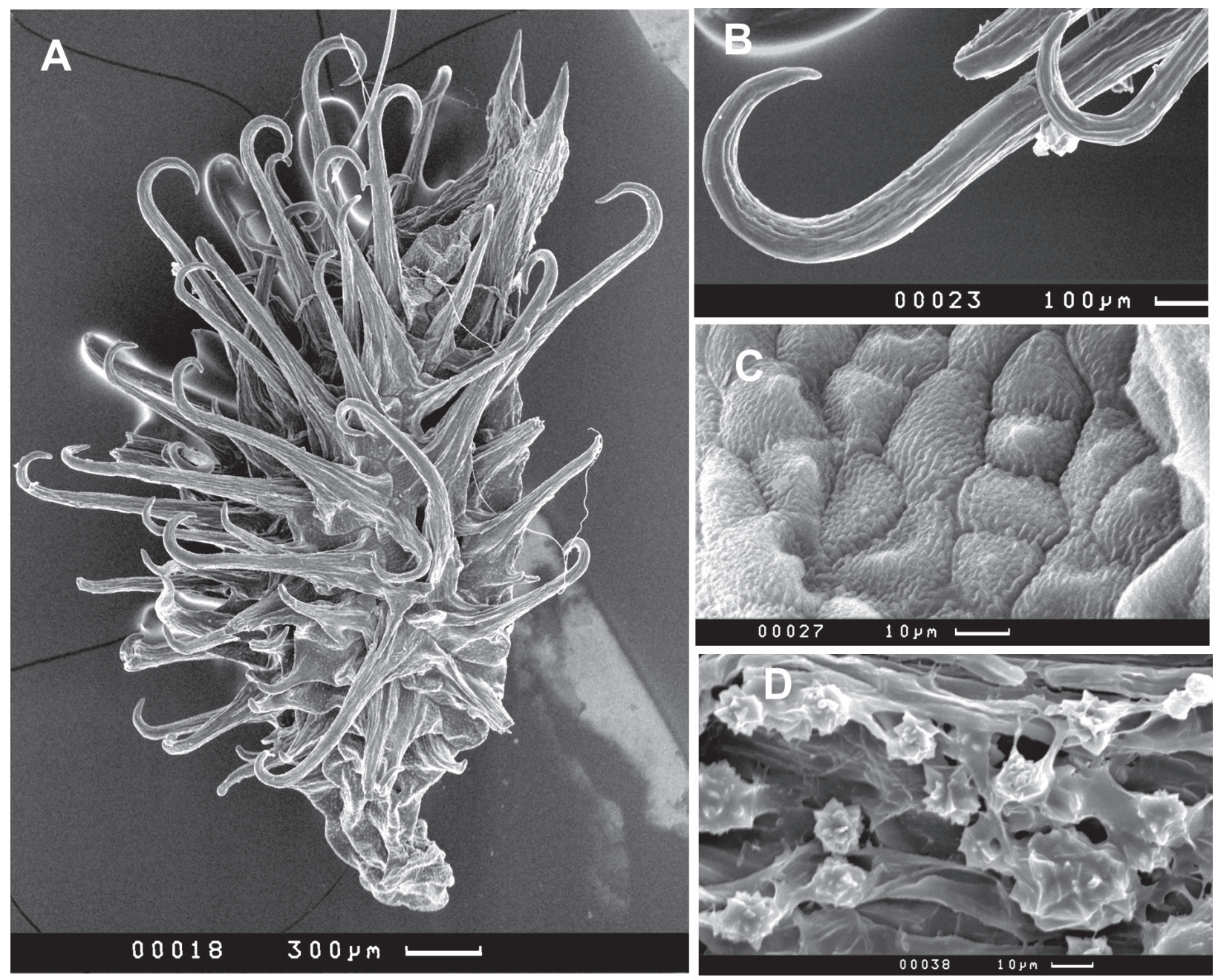

Fig. 2. Sanicula. A, B, C - S. giraldi. A - a mericarp with two large calyx teeth and numerous hooked spines. B - Spine apex with smooth fine relief. C - spine base, cell borders sunken, outer periclinal walls convex and with hemispherical projectiobs, fine relief rugulate-tuberculate. D - S. europaea, druses of crystals on commissure.

$\mathrm{b}$ - rather thick crust, smooth (Fig. 8B); c - rough crust (Fig. 8A); d - with small platelets (Fig. 8A, E).

To describe hairs and emergences (Table 2), the following characters were used:

Type. b - simple hairs (Fig. 9A-E, G, H); c1 - hooked spines (Fig. 1J, 2A); c2 - anchorlike glochidia (Fig. 9F); c3 - multicellular straight bristles (Fig. 1K); d -scales (Fig. 1M, N); e tubercles (Fig. 1O).

Form of simple hairs. a - ribbon-like (Fig. 9A, B); b-subulate (Fig. 4G, 9C); c-hooked (Ostroumova, 2018, Fig. 1d, f: Anthriscus sylestris).

Density of hairs. $a-$ sparse; $b$ - dense.

Hair length. a - very short $(>0.1 \mathrm{~mm})$; short $(0.1-1.0 \mathrm{~mm})$; long $(>1 \mathrm{~mm})$.

Pedestals. $\mathrm{n}-$ absent (Fig. 9B, C, H); $\mathrm{y}-$ present (Fig. 9D, G).

Tufted hairs. $\mathrm{n}-$ absent (Fig. 9B, C); $\mathrm{y}-$ present (Fig. 9E).
Fine relief (cuticular foldings). a - smooth (Fig. 2B, 9C); b - sparsely striate (Fig. 9F); c - striate; $\mathrm{d}$ - sparsely rugulate; e - rugulate (Fig. $9 \mathrm{H}) ; \mathrm{f}-$ tuberculate (Fig. 1L, 4G, 9B-E).

\section{Results}

The fruits of most species of the family Apiaceae, when ripe, split into two mericarps. Each mericarp has 5 ribs - two marginal and three dorsal (one median and two lateral); the ribs contain large vascular bundles, and there are valleculas (grooves) between the ribs (Fig. 1D, 7I). The Sajanella monstrosa mericarps, unlike most of the species, have 7 ribs. All the ribs can be similar, or the marginal ribs differ from the dorsal ones in size and shape. The genera Caucalis L. (Fig. 1J), Daucus L., and Turgenia Hoffm. have low primary ribs and large secondary ribs with spines. 

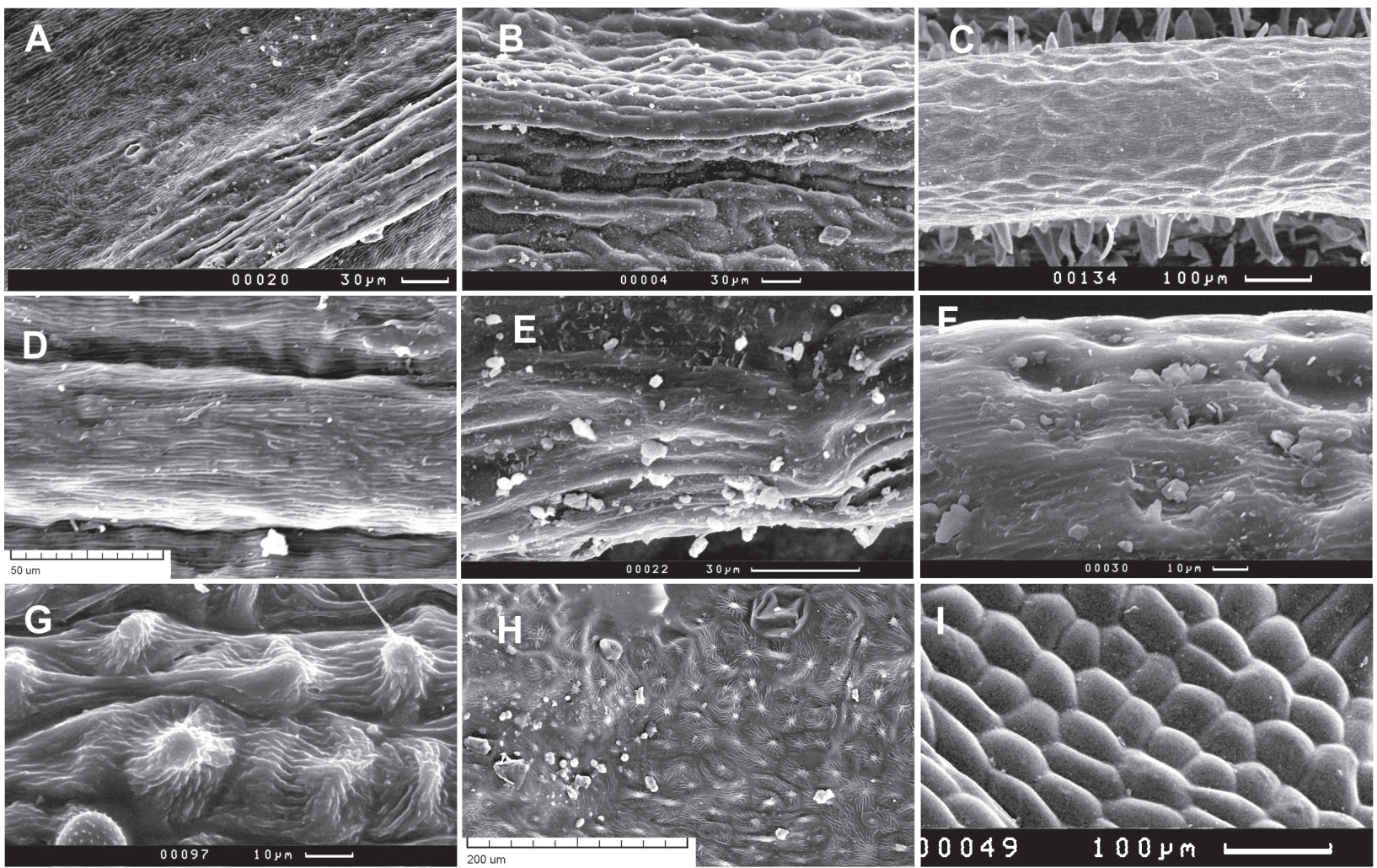

Fig. 3. Rib ridges and cell size. A - Vicatia atrosanguinea, longitudinally sulcate dorsal rib (lower right corner) and undulate surface of vallecula without cell borders, with striate and rugulate fine relief; a stoma is on the fruit level, cuticle around the stoma is usual. $\mathrm{B}$ - Bupleurum multinerve with oblong cells on the dorsal rib. $\mathrm{C}-$ Pachypleurum alpinum with isodiametic cells on the dorsal rib. D - Thysselinum palustre with smooth dorsal rib. E - Angelica decurrens with longitudinally sulcate edge of marginal rib. F - Peucedanum morisonii with concave cells along the edge of marginal rib. G, H - Xanthoselinum alsaticum, cell on the basal part of marginal winged rib: cell borders sunken, outer periclinal walls with acute projections, cuticle striate-knotted. I - Ostericum palustre with large exocarp cells, borders sunken, outer periclinal walls convex and domed.

With a magnification of $100-3000 \times$, the surface of the mericarp is not uniform: the ribs, different parts of the valleculas, and the distal parts of the wings can have a different appearance. The most characteristic features for the species are usually confined to the valleculas and to the basal parts of the ribs.

The characteristics of the studied species are shown in Tables 1 and 2.

The micromorphology of the apex of the mericarp (stylopodium, calyx teeth, and adjacent areas of the fertile part) differs from the rest of the surface; for descriptions, we used the middle and lower parts of the mericarp. The traits of cells and fine relief refer to the valleculas and rib bases.

The ridges of the dorsal ribs usually differ from the valleculas; they are most often longitudinally sulcate, and the boundaries of the cells on them are indiscernible; sometimes elongated cells are visible on the ridges, and cells are rarely isodiametric. If the ribs do not have a pronounced ridge, its surface is smooth or similar to the surface of valleculas. In species with dorsally compressed fruits and winged marginal ribs (genera Anethum, Angelica, Ferula, Haloselinum, Heracleum, Peucedanum, Thyselinum, and Xanthoselinum), the margin of the wing is usually covered with isodiametric cells with concave outer walls (Fig. 3F) and sometimes longitudinally sulcate (Fig. 3E). This trait is found in many species and has no diagnostic value.

Epidermal cells in most species are $<35 \mu \mathrm{m}$ in diameter (elongated cells - in width); in Anthriscus sylvestris, Apium graveolens, Cnidium cnidiifolium, Haloselinum falcaria (on the wing), Phlojodicarpus sibiricus, and Xanthoselinum alsaticum, both small and large cells are found.

Large cells ( $35 \mu \mathrm{m}$ and more) of the outer epidermis (exocarp) with rigid walls, retaining their shape during fruit maturation, are rare in the Apiaceae and usually characterize all species of any genus. In Siberia, these genera are Aulacospermum Ledeb. (Fig. 6D, H), Hansenia (Fig. 1E, F), Ostericum Hoffm. (Fig. 3I, 6C), Pleurospermum Hoffm., and Tilingia Regel. The parenchyma of the mesocarp in these 
taxa is partially destroyed, and cavities are formed under the epidermis. In a light stereomicroscope, the surface of such fruits looks shiny and grainy, which makes it possible to determine species without an electron microscope.
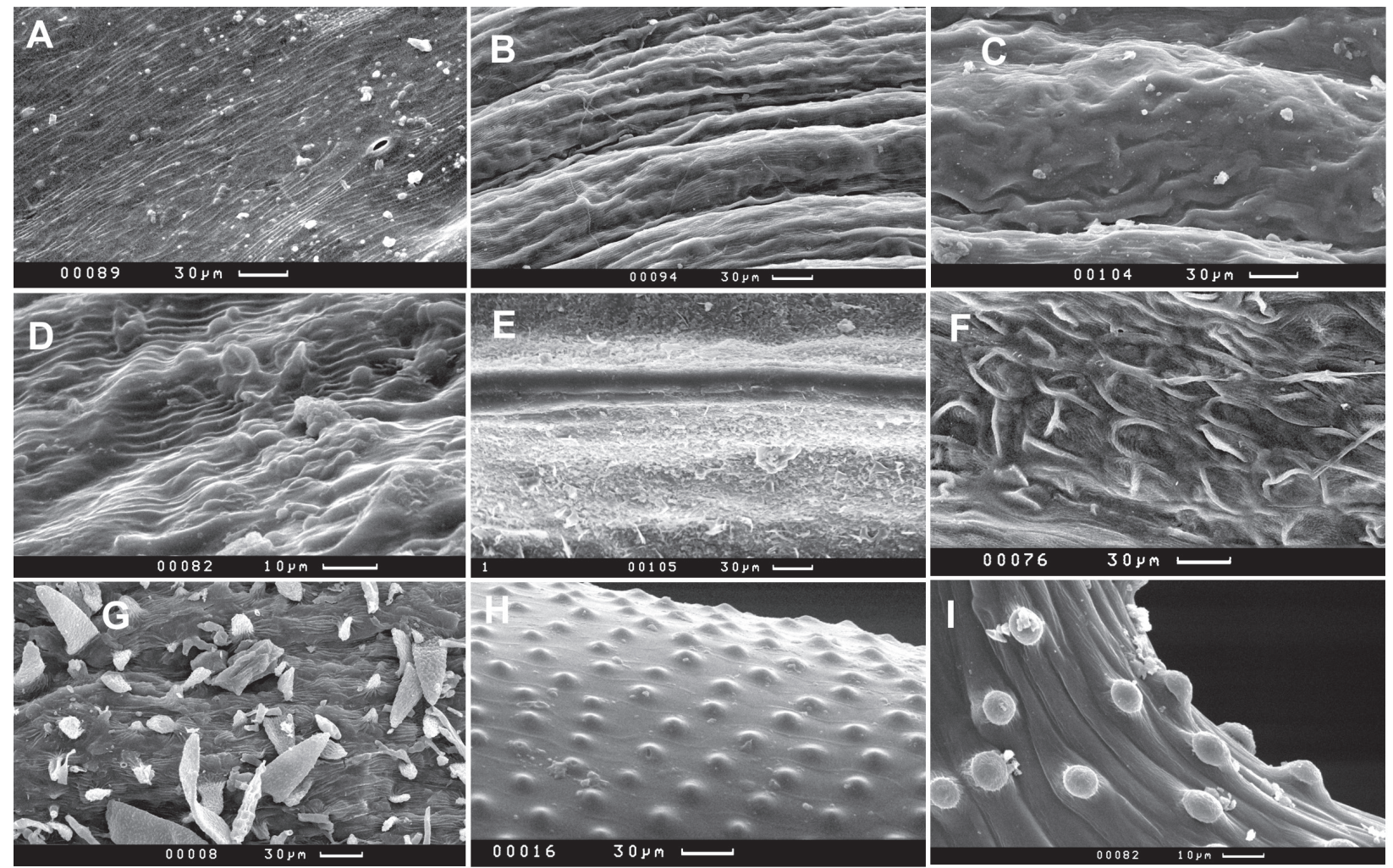

Fig. 4. Surface patterns when cell borders indistinct. A - Cenolophium denudatum, surface smooth, fine relief striate, usual around a stoma B - Sium sisaroideum, surface longitudinallu rugate, fine relief striate. C - Seseli strictum, surface irregularily rugate. D - Carum carvi, wax removed with diethyl ether, surface foveate-tuberculate. E - Bupleurum bicaule, smooth rib, undulate surface of valleculas, numerous wax platelets. F - Angelica anomala, surface with flattened projections. G - Seseli libanotis, surface with acute projections (cuticle striate-knotted) and simple hairs (cuticle tuberculate). H - Anthriscus sylvestris, surface with dome-like projections. I - Daucus carota, short capitate papillae with rugulate heads.
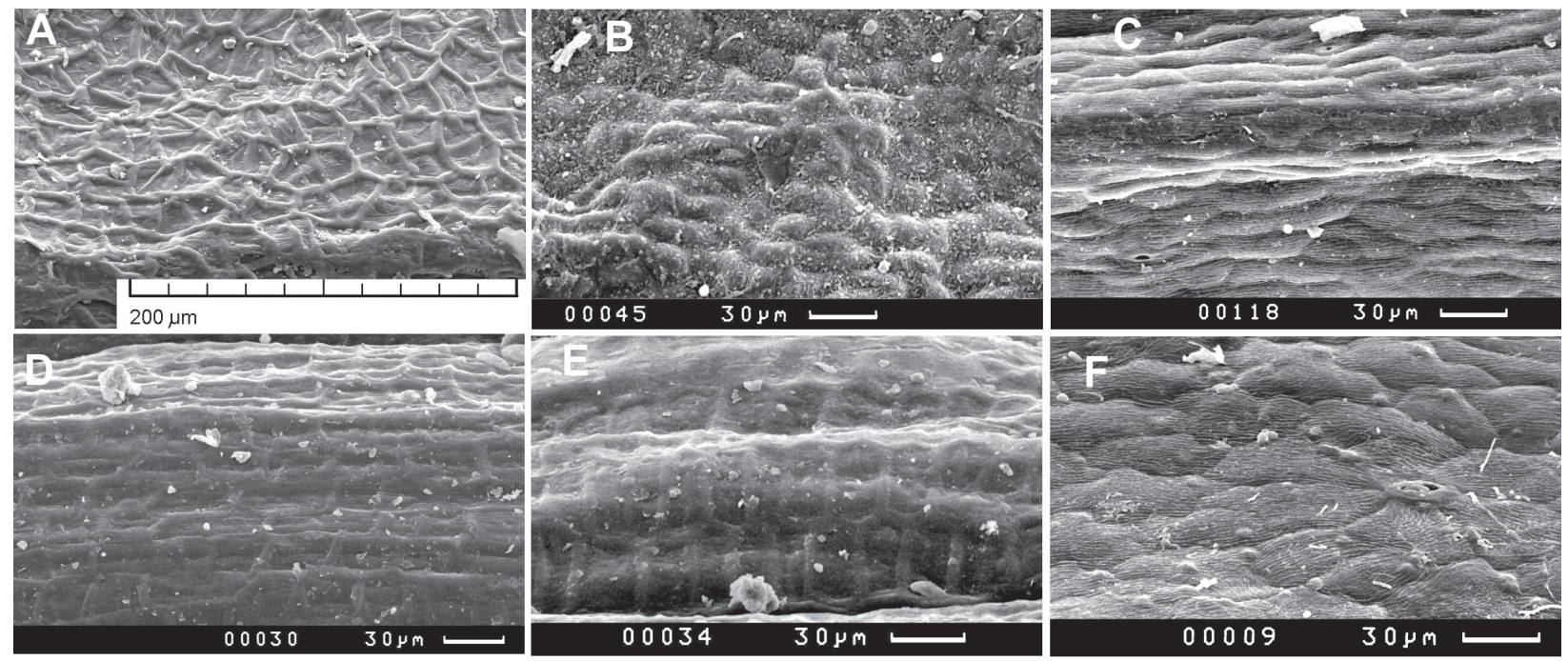

Fig. 5. Cell arrangement and outlines. A - Coriandrum sativum, cells arranged at random, borders raised, outer wall flat, cuticle smooth. B - Bupleurum krylovianum, cells arranged at random, borders sunken, outer walls convex, numerous wax platelets. C - Anethum graveolens, oblong cells in longitudinal rows, cuticle striate. D, E - Chaerophyllum prescottii, cells in longitudinal rows, on a rib (D) cells elongated longituninally, on a vallecula (E) elongated transversely. F - Conioselinum tataricum, cell borders sunken, cell arranged at random, cuticle striate and rugulate. 


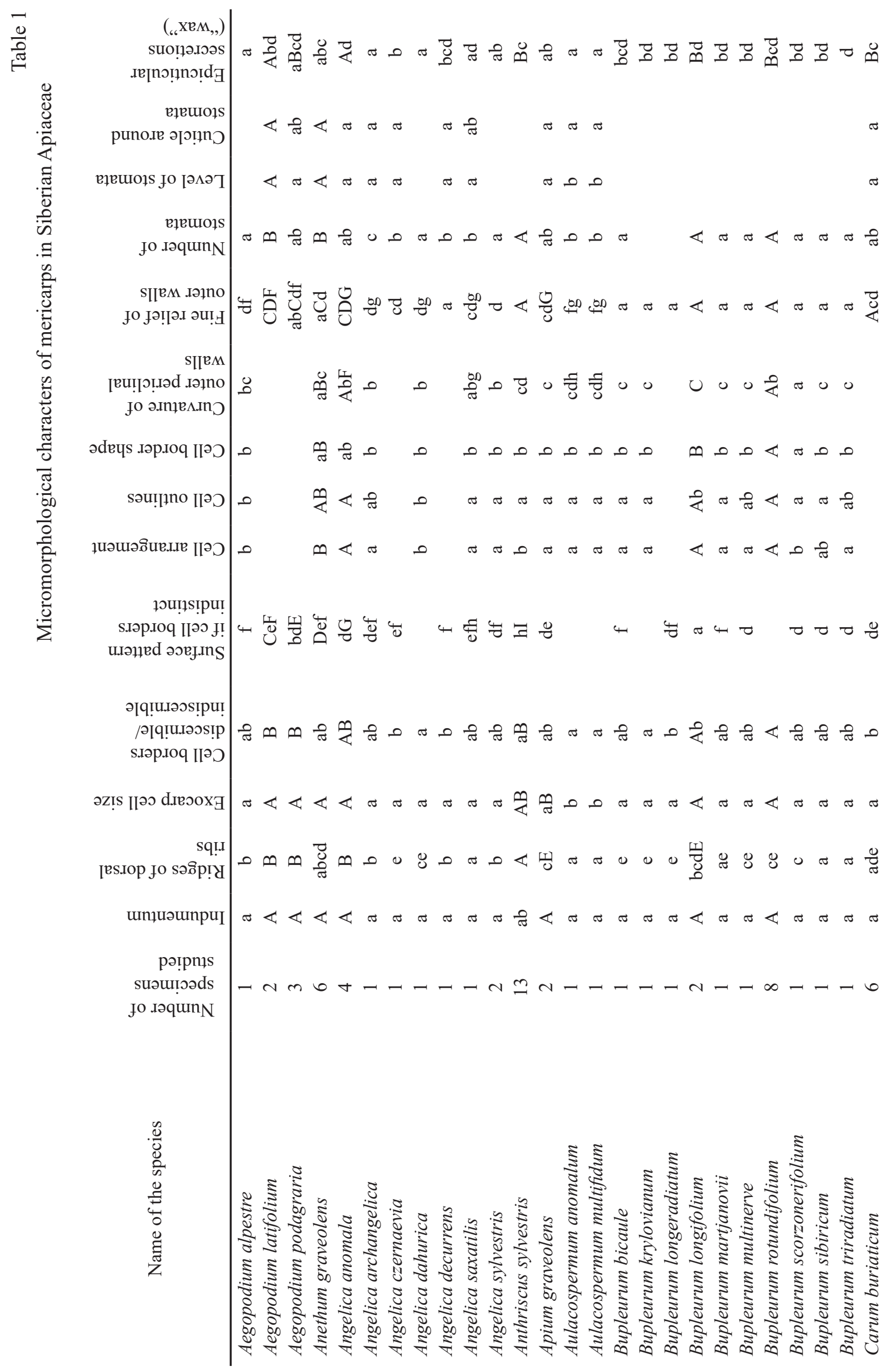




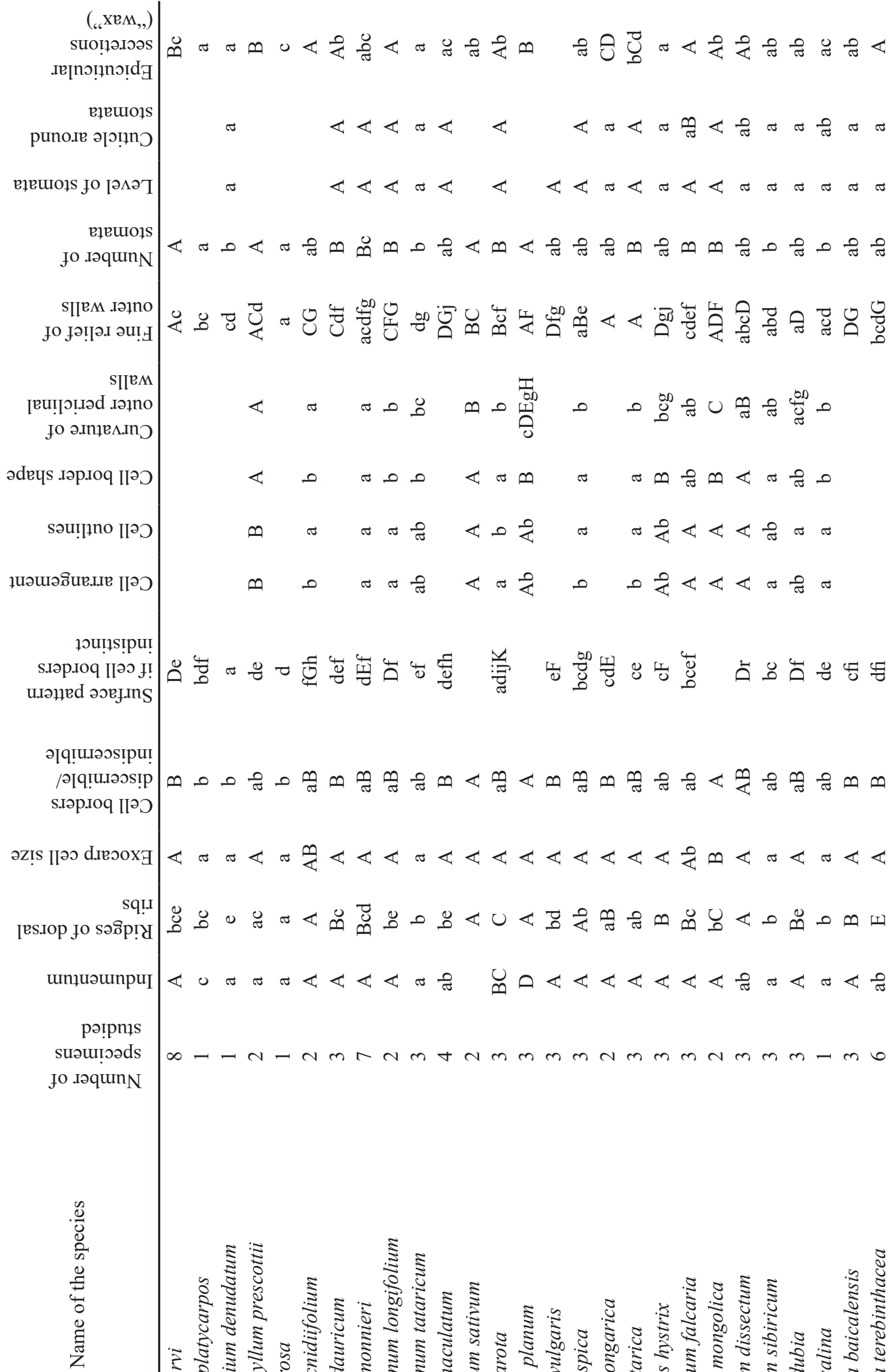




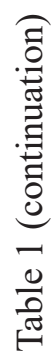

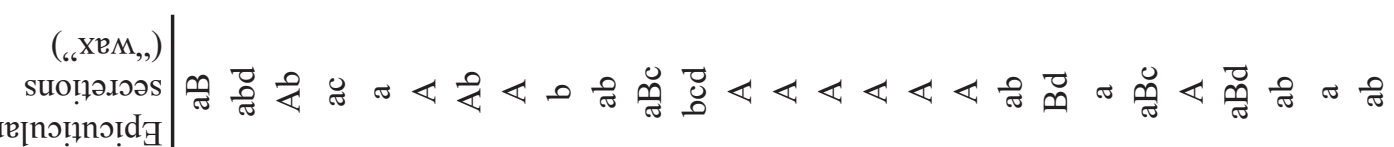

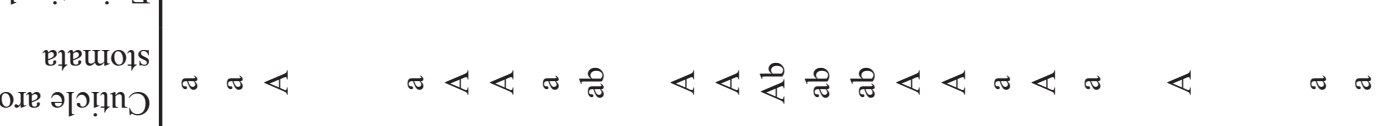

$$
\begin{aligned}
& \text { вұвшоя јо ГวләТ }
\end{aligned}
$$

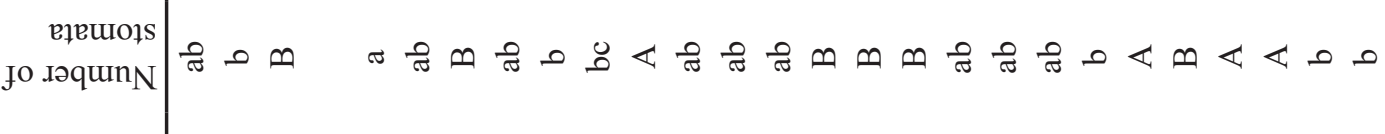

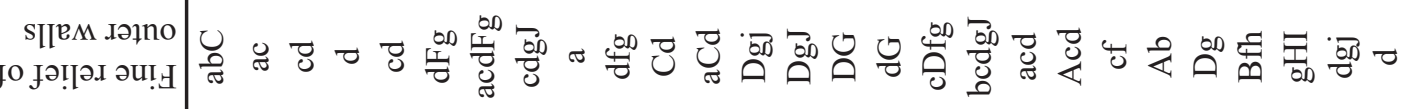

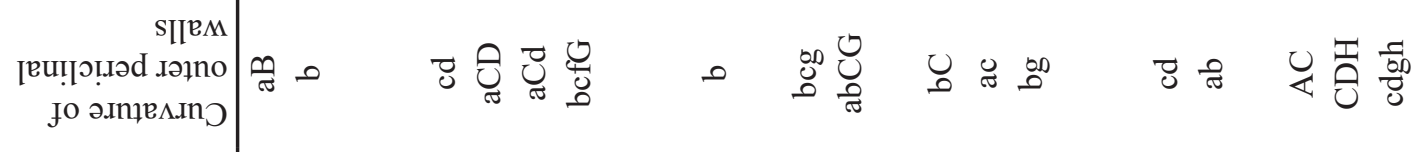

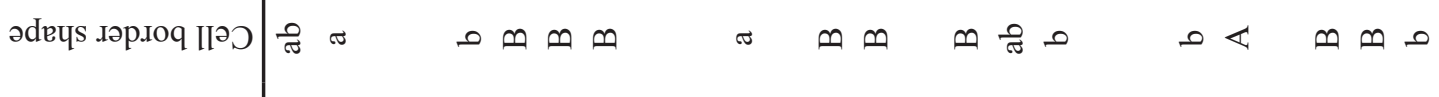

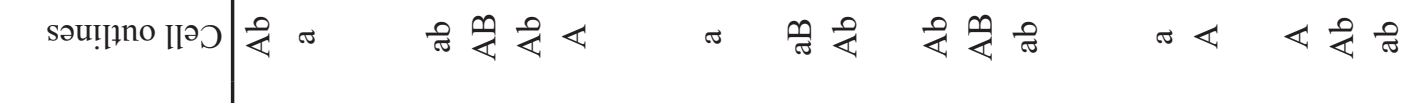

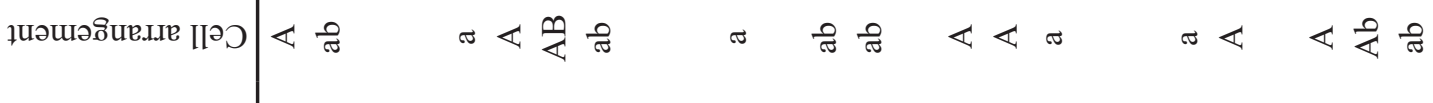

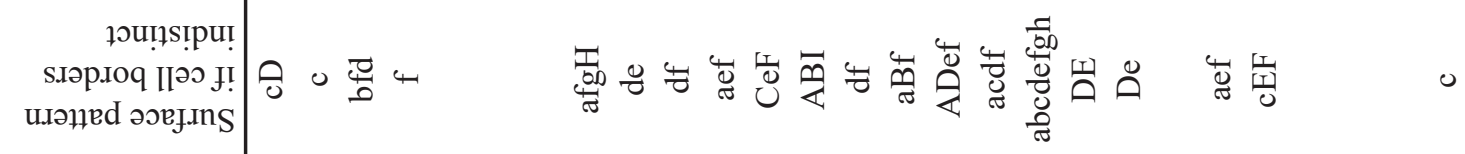

$$
\begin{aligned}
& \text { sıวр.оо ІІәว }
\end{aligned}
$$

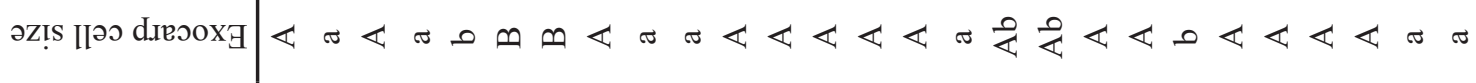

$$
\begin{aligned}
& \text { [вs.op jo səôp! }
\end{aligned}
$$

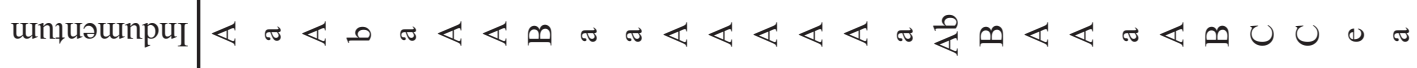

$$
\begin{aligned}
& \text { pə!pnıs }
\end{aligned}
$$

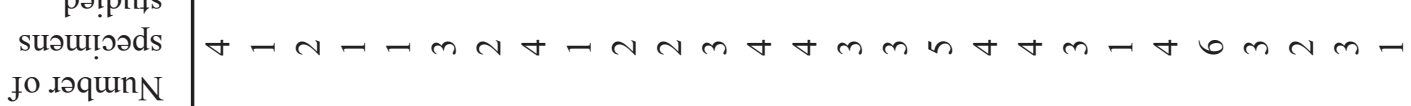

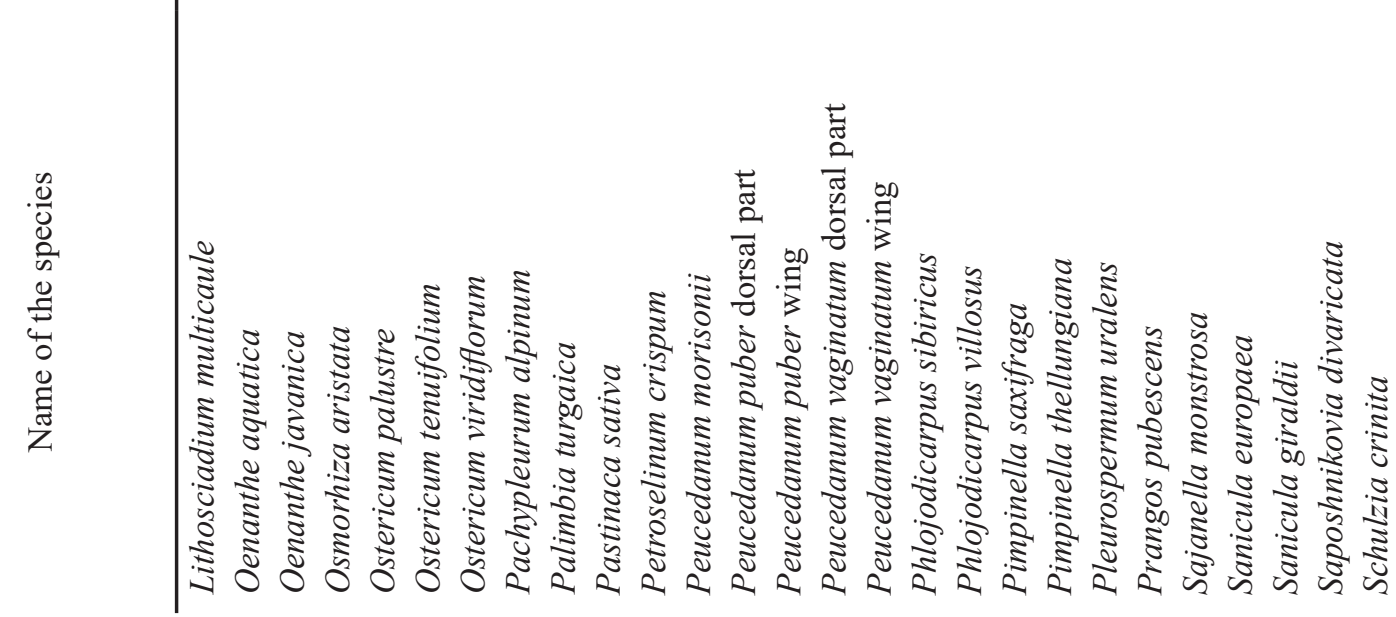


है
$\frac{0}{0}$
$\frac{0}{0}$

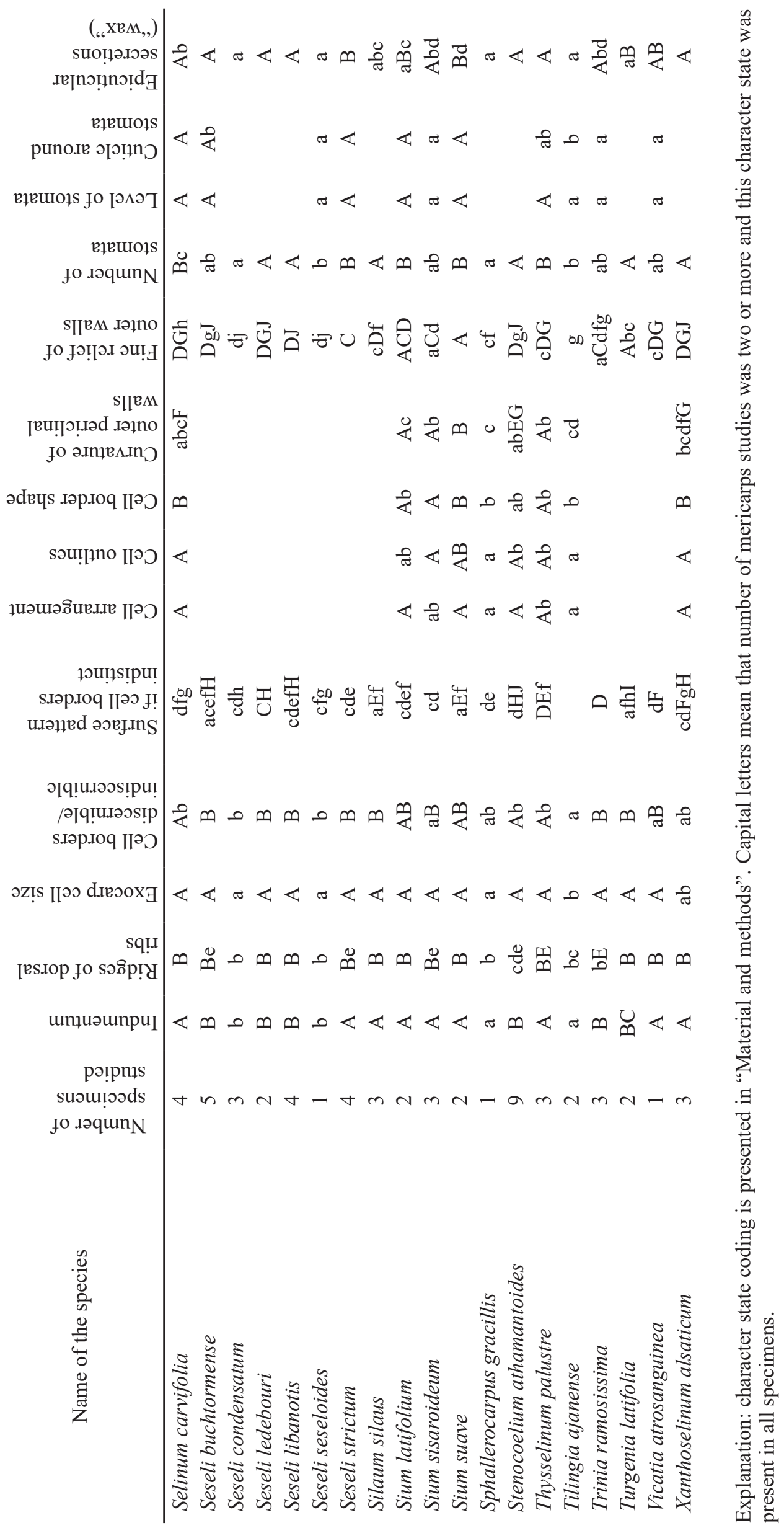


Table 2

The characters of hairs and emergences in Siberian Apiaceae

Name of the species

Angelica anomala immature

Anthriscus sylvestris

Caucalis platycarpos

Conium maculatum

Daucus carota

Eryngium planum

Heracleum dsssectum

Heracleum sibiricum immature

Kitagawia terebinthacea

Osmorhiza aristata

Pachypleurum alpinum

Phlojodicarpus sibiricus

Phlojodicarpus villosus

Sajanella monstrosa

Sanicula europaea

Sanicula giraldii

Saposhnikovia divaricata

Seseli buchtormense

Seseli condensatum

Seseli ledebouri

Seseli libanotis

Seseli seseloides

Stenocoelium athamanthoides

Trinia ramosissima

Turgenia latifolia

\begin{tabular}{|c|c|c|c|c|c|c|}
\hline 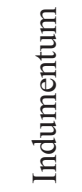 & 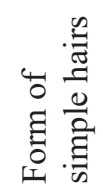 & 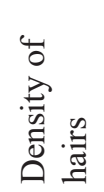 & 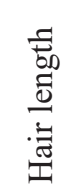 & 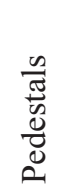 & 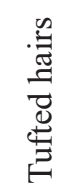 & 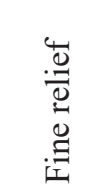 \\
\hline $\mathrm{b}$ & $\mathrm{a}$ & $\mathrm{a}$ & $\mathrm{b}$ & $\mathrm{n}$ & $\mathrm{n}$ & hi \\
\hline $\begin{array}{c}\mathrm{b} \\
\mathrm{c} 1 \mathrm{c} 3\end{array}$ & $\mathrm{c}$ & $\mathrm{b}$ & $\mathrm{b}$ & $\mathrm{y}$ & $\mathrm{n}$ & $\begin{array}{l}\text { bgi } \\
\text { bi }\end{array}$ \\
\hline b & $\mathrm{b}$ & $\mathrm{a}$ & $\mathrm{a}$ & $\mathrm{n}$ & $\mathrm{n}$ & $\mathrm{g}$ \\
\hline $\begin{array}{c}\mathrm{bc} 2 \\
\mathrm{~d}\end{array}$ & $\mathrm{~b}$ & $\mathrm{a}$ & $\mathrm{b}$ & yn & $\mathrm{n}$ & $\begin{array}{l}\text { bhi } \\
\text { bf }\end{array}$ \\
\hline $\mathrm{b}$ & $\mathrm{a}$ & $\mathrm{a}$ & $\mathrm{b}$ & $\mathrm{n}$ & $\mathrm{n}$ & $\mathrm{b}$ \\
\hline $\mathrm{b}$ & $a b$ & $\mathrm{a}$ & $a b$ & $\mathrm{n}$ & $\mathrm{n}$ & bfh \\
\hline $\mathrm{b}$ & $\mathrm{b}$ & $\mathrm{b}$ & $\mathrm{a}$ & $\mathrm{n}$ & $\mathrm{n}$ & gh \\
\hline $\mathrm{b}$ & $\mathrm{b}$ & $\mathrm{a}$ & $\mathrm{b}$ & $\mathrm{y}$ & & $\mathrm{dg}$ \\
\hline $\mathrm{b}$ & $\mathrm{b}$ & $a b$ & $\mathrm{ab}$ & $\mathrm{n}$ & $\mathrm{n}$ & dgh \\
\hline b & & $\mathrm{a}$ & & & & $\mathrm{h}$ \\
\hline $\mathrm{b}$ & $\mathrm{a}$ & $\mathrm{b}$ & $a b c$ & $\mathrm{n}$ & $\mathrm{n}$ & bdgh \\
\hline $\mathrm{b}$ & $\mathrm{a}$ & $\mathrm{a}$ & $a b$ & $\mathrm{n}$ & $\mathrm{n}$ & bdf \\
\hline $\mathrm{c} 1$ & & & & & & $\mathrm{bc}$ \\
\hline $\mathrm{c} 1$ & & & & & & $\mathrm{bc}$ \\
\hline $\mathrm{e}$ & & & & & & \\
\hline $\mathrm{b}$ & $\mathrm{b}$ & $\mathrm{b}$ & $\mathrm{ab}$ & $\mathrm{n}$ & $\mathrm{y}$ & ghi \\
\hline b & $\mathrm{ab}$ & $\mathrm{b}$ & $a b c$ & $\mathrm{n}$ & $\mathrm{n}$ & 0 \\
\hline $\mathrm{b}$ & $\mathrm{b}$ & $\mathrm{b}$ & $a b$ & $\mathrm{n}$ & $\mathrm{n}$ & dgf \\
\hline $\mathrm{b}$ & $\mathrm{b}$ & $a b$ & $a b$ & $\mathrm{n}$ & $\mathrm{n}$ & gh \\
\hline $\mathrm{b}$ & $\mathrm{b}$ & $\mathrm{b}$ & $\mathrm{ab}$ & $\mathrm{n}$ & $\mathrm{n}$ & $\mathrm{dfh}$ \\
\hline $\mathrm{b}$ & $\mathrm{b}$ & $a b$ & $a b$ & ny & ny & ghi \\
\hline $\mathrm{b}$ & $\mathrm{b}$ & $\mathrm{a}$ & $\mathrm{a}$ & ny & $\mathrm{n}$ & tg \\
\hline $\mathrm{bc} 2$ & $\mathrm{~b}$ & $\mathrm{a}$ & $a b$ & $\mathrm{y}$ & $\mathrm{y}$ & \\
\hline
\end{tabular}

Explanation: character state coding is presented in "Material and methods".

It is useful to study the boundaries of cells at a magnification of 300-1000x. For example, at a magnification of $100 \mathrm{x}$, it seems that some areas of the mericarp surface of Kadenia dubia, Oenanthe aquatica, and Thyselinum can be described as "reticulated" in the terminology of Stearn (1983). At a higher magnification, however, it is impossible to outline the cells.

Elongated cells are rare in valleculas and are mostly found together with isodiametric cells. Predominantly long cells are noticed in Aegopodium alpestre, in the middle valleculas of Peucedanum puberulum, while in Chaerophyllum prescottii, the cells in the grooves are elongated in the transverse direction (Fig. 5E), and on the ribs, longitudinally (Fig. 5D).
The cells are arranged in random order or in rows, and the rows are observed not only on elongated fruits (Chaerophyllum prescottii, Aegopodlium alpestre), but on wider fruits (Anethum graveolens Fig. 5C), Ostericum viridiflorum, between dorsal ribs in Peucedanum puberulum, in some areas of the species Bupleurum and Ferula).

Cell boundaries (anticlinal walls) are sunken or raised. The surface of the outer periclinal wall is most often flat or concave; it is also convex, domeshaped, and sometimes the cells have outgrowths acute, hemispherical, flattened. It should be noted that for anatomical studies, the fruits are hydrated, and the outer walls of exocarp cells on transverse sections always looks flat or slightly convex (Ostroumova, Kljuykov, 2015). 

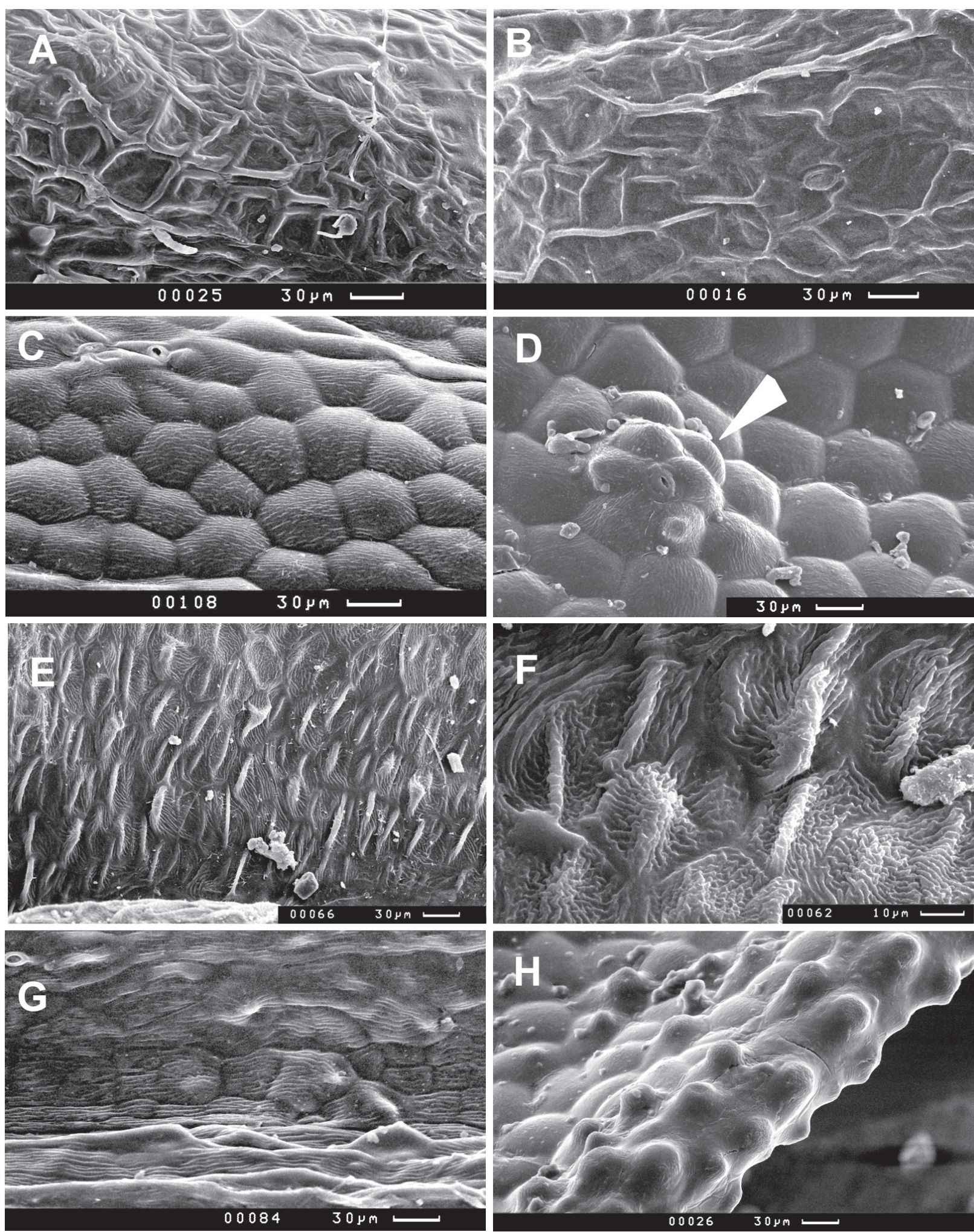

Fig. 6. Curvature of outer periclinal walls. A - Heracleum dissectum (marginal winged rib) and B - Lithosciadium multicaule: flat outer walls, raised borders, smooth fine relief. C - Ostericum tenuifolium, convex outer walls, sunked borders, rugulate fine relief. D - Aulacospermum multifidum, convex and domed (arrowhead) outer walls, rugulate fine relief. E, F - Selinum carvifolia, flattened projections, oriented transversely, cuticle rugulate, E - cell borders indistinct, $\mathrm{F}$ - cell borders distinct, sunken. $\mathrm{G}-$ Ferulopsis hystrix, outer walls flat and with acute projections. $\mathrm{H}-$ Aulacospermum anomalum, cells with hemispherical projections on a ridge of rib. 

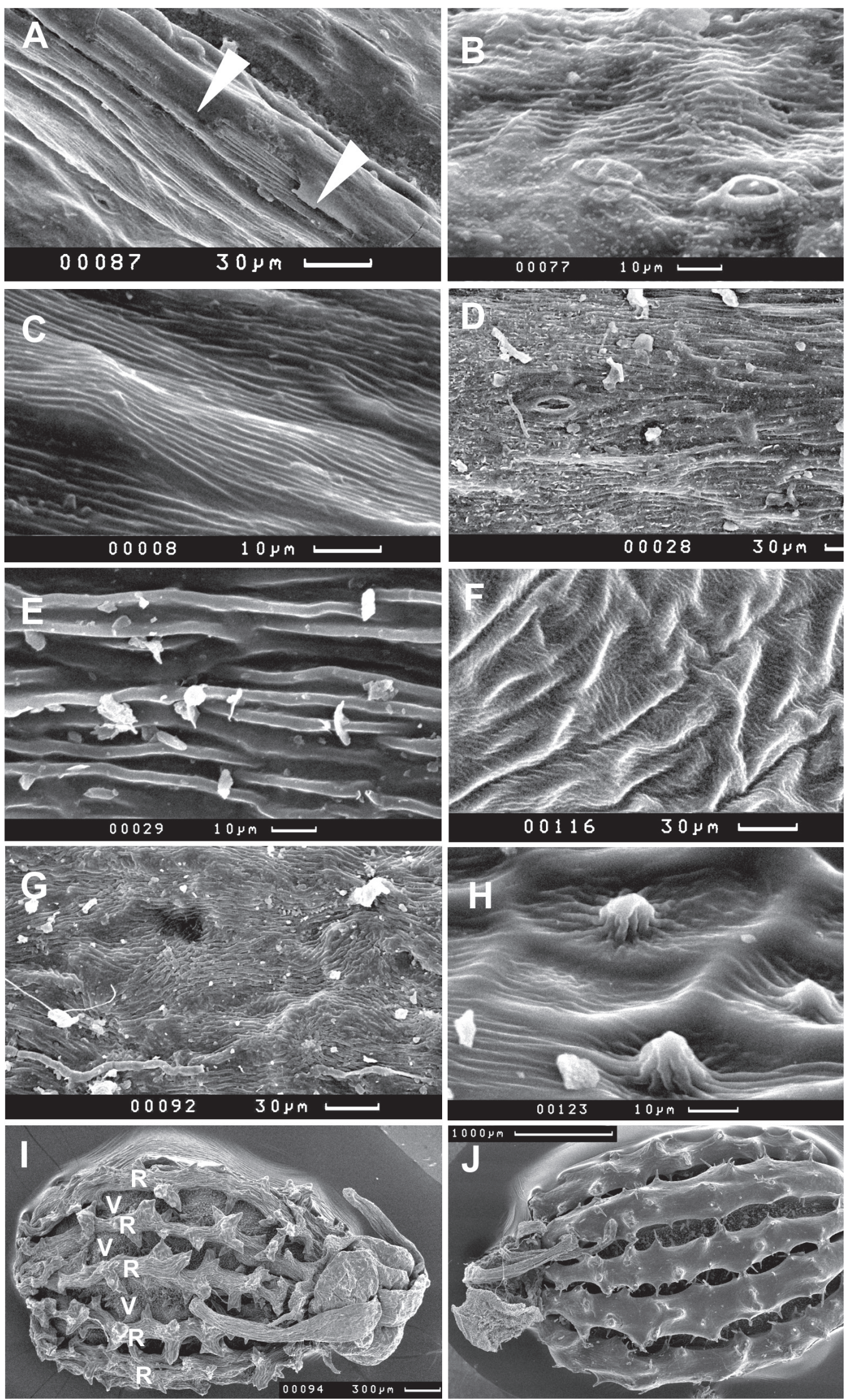

Fig. 7. Fine relief of outer wall. A - Kadenia dubia, wax layer (arrowhead) hides striate relief if cell wall. B - Aegopodium latifolium, sparsely striate relief. $\mathrm{C}$ - Angelica archangelica, striate relief. $\mathrm{D}$ - Peucedanum morisonii, striate relief. E - Ferula caspica, coarsely striate. F - Conioselinum longifolium, sparsely rugulate. G - Kitagawia baicalensis, rugulate. $\mathrm{H}$ - J Stenocoelium athamantoides, $\mathrm{H}$ - dorsal rib with striate-knotted cuticle. I - immature fruit ( $\mathrm{R}$ - rib, $\mathrm{V}$ - vallecula) and $\mathrm{J}$ - mature fruit. 

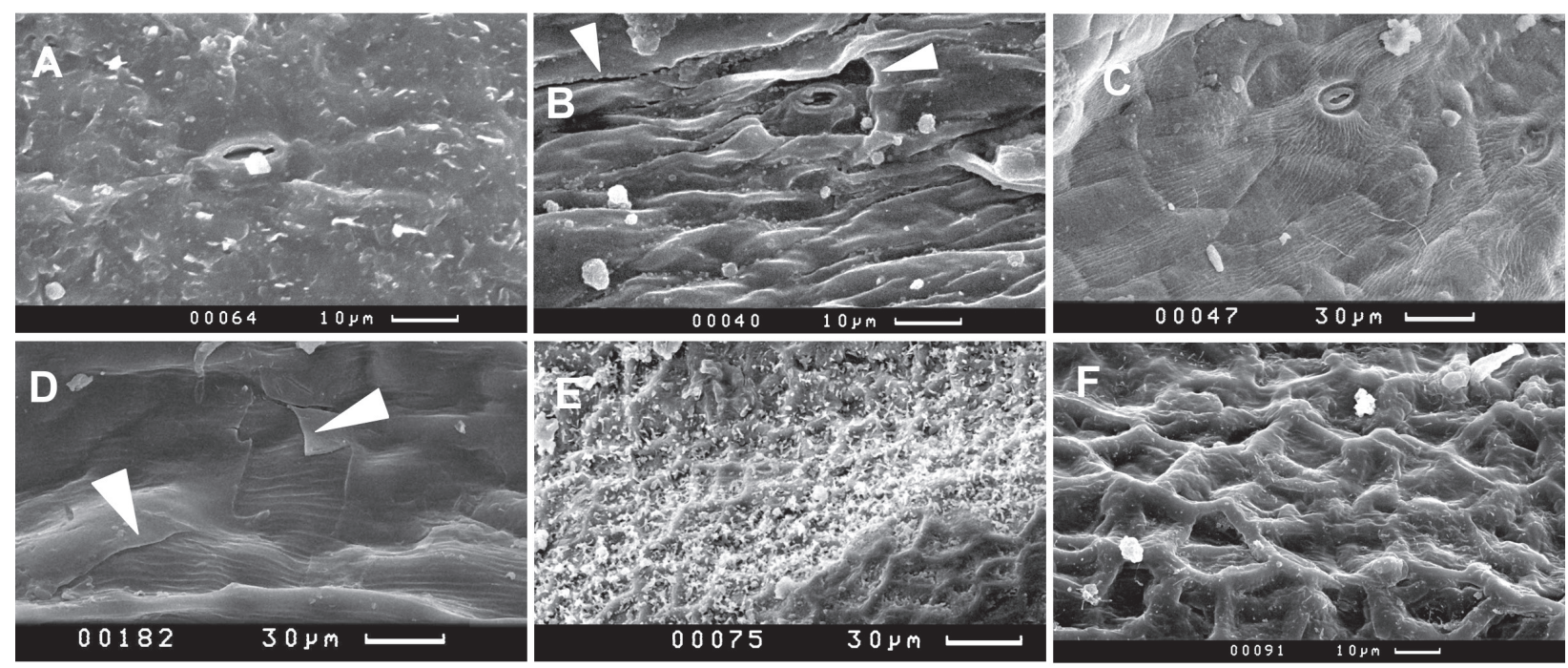

Fig. 8. Stomata and epicuticular wax. A - Ferula soongarica, rough wax layer with platelets, a stoma at fruit level, its cuticle usual. B - Palimbia turgaica, remnants of smooth wax layer (arrowhead), a stoma at fruit level, its cuticle usual. C - Kadenia salina, cuticle striate radiating around a stoma. D - Kitagawia baicalensis, smooth wax layer (arrowhead). E, F-Bupleurum rotundifolium, E- native fruit, numerous wax platelets. F-wax removed with hot water, cell borders raised, outer cell walls concave, cuticle smooth.

The fine relief of the cell wall is most often striate (on flat and concave cells) or rugulate (usually on convex cells), or occasionally smooth; on sharp outgrowths, it is striato-knotted. Several relief forms are often found on the surface of one mericarp. It is one of the least variable micromorphological features: almost all species have one or several variants, which are present in all studied mericarps.

In those cases where the boundaries of the cells are indistinguishable, we described the general appearance of the surface, as it is visible at a magnification of about $30-100 x$ - smooth, undulate, irregularly rugate (elongated sinuous elements); longitudinally rugate (more or less straight parallel elements), foveate-tuberculate (small elements of various shapes), and longitudinally sulcate (long parallel grooves). The foveate-tuberculate surface probably appears when the thin outer wall is pressed against the dry contents of the cell. Kadenia dubia and Cnidium monnieri sometimes have transverse wrinkles more than one cell in length. On the whole, the surface of dry mericarps without cell boundaries is difficult to describe; on the same fruit, usually several variants can be seen, and the intraspecific variability is great; in many cases different samples of the same species do not have any common states of this trait.

On the surface, there are often outgrowths much smaller than a cell (sharp, hemispherical, flattened projections or papillae). In many species the form of outgrowths is a stable feature: flattened in Angelica anomala (Fig. 4F), Cnidium cnidiifolium, and Selinum carvifolia (Fig. 6E, F), acute in Pachypleurum alpinum, Phlojodicarpus villosus, Seseli buchtormense, S. ledebourii (Fig. 1I), S. libanotis (Fig. 4G), and Stenocoelium athamantoides; hemispherical in Kitagawia terebinthacea and Turgenia latifolia. Acute or hemispherical projections arranged in regular rows are an attribute of Anthriscus sylvestris. Stenocoelium athamantoides (Fig. 9D) and Xanthoselinum alsaticum (Fig. 3GH) carry papillae and sharp outgrowths on the surface, regardless of whether the cell boundaries are discernible or not; the same was noticed in relation to flattened projections on the fruits of Selinum carvifolia (Fig. 6E, F).

The stomata on mature fruits are not always noticeable and are sparse (1-3 per square $\mathrm{mm}$ ); they are located on the plane of the exocarp or they are raised; the cuticle around the stomatal pore is usual for this area of the fruit or smooth; in rare cases, there are radially diverging cuticular folds.

The diversity of epicuticular secretions ("wax") on the fruits studied is small. Sometimes the wax layer is very thin, and the detail of the cell surface is clearly visible. A smooth or rough crust, a few microns thick, masks surface details: cell boundaries, the shape of anticlinal walls, and the fine relief. Granules can be seen on the crust surface, but SEM cannot tell us the difference between wax particles and dust, so we did not use granules as the character state. On some fruits of Aegopodium L., Angelica L. (Fig. 3E), Ferula L. (Fig. 8A), Pimpinella L., 

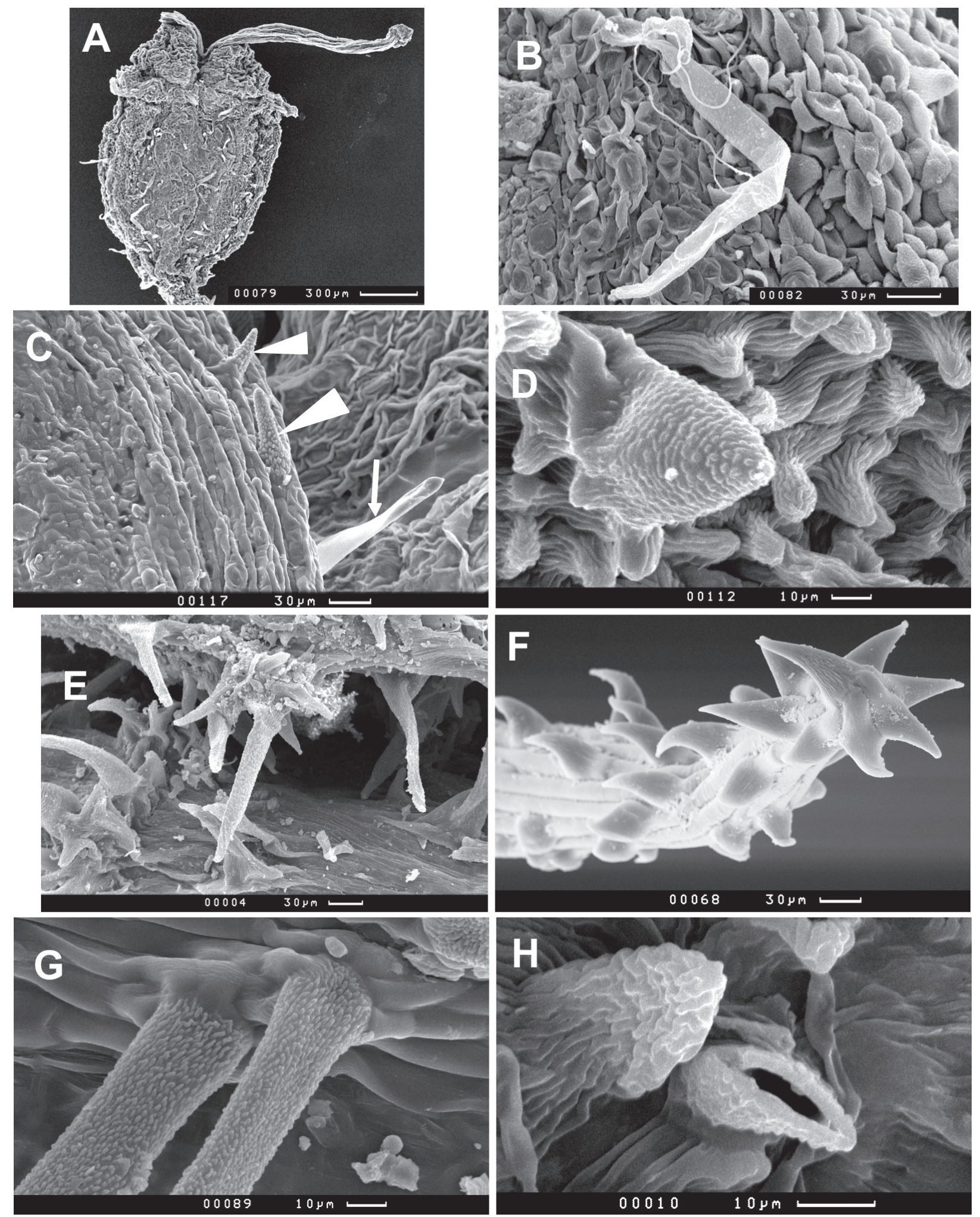

Fig. 9. Indumentum. A, B - Angelica anomala, immature fruit, ribbon-like hair with tuberculate surface. $\mathrm{C}-$ Heracleum sibiricum, Immature fruit, ribbon-like hair with smooth surface (arrow) and acicular hairs with tuberculate surface (arrowheads). D - Stenocoelium athamantoides, a hair with a pedestal (cuticle rugulate-tuberculate) and numerous acute projections and papillae. E - Seseli buchtormense, tufted hairs with tuberculate surface. F - Turgenia latifolia, apex of glochidium with sparse striate surface. G - Daucus carota, hairs with pedestals, surface rugulate-tuberculate. $\mathrm{H}$ - Seseli libanotis, a broken hair. 
Sanicula, and Trinia Hoffm., platelets are occasionally found; however, on the fruits of the genus $\mathrm{Bu}$ pleurum L., platelets are especially numerous. The plates are $1-2 \mu \mathrm{m}$ in size, located perpendicular or at an angle to the surface. Crust is usually absent on pubescent fruits and fruits with large, convex exocarp cells.

The characters of hairs and emergences are listed in Table 2. The longest hairs $(1.1 \mathrm{~mm})$ are found in Phlojodicarpus villosus and Seseli condensatum. The wall thickness of the hairs can be determined by stubs: for example, in Seseli libanotis (Fig. 9H) and S. seseloides it is about $2 \mu \mathrm{m}$, and $1 \mu \mathrm{m}$ in Phlojoducarpus villosus. It can also be estimated indirectly based on hair shape and surface sculpture.

Among the studied species, ribbon-like, thinwalled, strongly flattened hairs with a smooth surface were noted only in Heracleum dissectum, and in one specimen of Sajanella monstrosa; in these species, the ovaries are densely pubescent, and as the fruit matures, some hairs fall off. $H$. sibiricum is characterized by glabrous fruits, but sometimes there are single ribbon-like smooth hairs and subulate hairs with a rugulate and tuberculate surface (Fig. 9C). Angelica anomala (Fig. 9B), Phlojodicarpus villosus, Sajanella monstrosa (Fig. $1 \mathrm{H})$, and Seseli condensatum have long ribbon-like hairs of irregular shape, but their fine relief is well-defined striate, rugulate, or tuberculate; the walls of the hairs are most likely thicker than those of the hogweed. Trinia ramosissima, as well as some specimens of Conium maculatum and Kitagawia terebinthacea, have very short $(20-30 \mu \mathrm{m})$ triangular hairs with a densely rugulate or tuberculate surface on the fruits. In other species with pubescent fruits, the hairs are subulate, sharp, with a well-defined fine relief. The hairs have multicellular pedestals in Anthriscus sylvestris, Daucus carota, Stenocoelium athamantoides (Fig. 9D), Turgenia latifolia, and Trinia ramosissima. Most species have solitary hairs, but Seseli buchtormense (Fig. 9E), Stenocoelium athamantoides, and Turgenia latifolia have tufted hairs. We have already noted in the Far Eastern material (Ostroumova, 2018) that the fruits of Pachypleurum alpinum, Phlojodicarpus villosus, and Sesel condensatum have the entire spectrum of hairs from small sharp prickles to ordinary hairs $50-100 \mu \mathrm{m}$ long. The same picture is observed on the fruits of Seseli ledebourii (Fig. 1I), Seseli libanotis (Fig. 4G), and Stenocoelium athamantoides (Fig. 9D), which are common in Siberia.

Zoochoric adaptations are visible on the fruits of some species studied. Fruits of Caucalis platy- carpos (Fig. 1J), Sanicula europaea, and S. giraldii (Fig. 2A) have hooked spines; anchor-like glochidia are on secondary ribs in Daucus catota and Turgenia latifolia. The fruits of Turgenia are especially powerfully "armed" - glochidia bear not only anchors at the end, but are also covered over the entire surface with small, sharp downward-facing prickles (Fig. 9F)

As most species of the subfamily Saniculoideae, Sanicula europaea (Fig. 2D) and S. giraldii have drused of calcium oxalate.

Fruits of Stenocoelium athamanthoides change their appearance on the late steps of ontogenesis drastically, its ribs inflate and almost hide valleculas (Fig. 7I, J).

In general, it should be noted that there is a significant intraspecific variability of micromorphological characters. In Table 1, characters stable within a species are shown in capital letters. Lower case letters indicate that this condition of the character varies within the species. Lower case letters were also used when only one sample was studied, and it is not yet possible to assess the degree of variability.

\section{Discussion}

When describing the micromorphology of botanical objects, the terminology proposed by Margarita R. Murley (1951) is often used, which was also adopted by Stearn (1983). M. Murley's work is a classic study of the seeds of the family Cruciferae; all terms are clearly defined and illustrated. The work was carried out using an optical stereomicroscope with a magnification of up to $45 \times$. Many terms are quite applicable to describe the surface as it is seen at 50-100× magnification. For example, "colliculate" usually corresponds to isodiametric cells with sunken borders and convex outer walls. "Aculeate" are small sharp outgrowths, regardless of whether the cell margins are noticeable or not. Compressed outgrowths, characteristic of some species of Apiaceae, were not found in crucifers, so a term has not been proposed for them. "Reticulate" can mean cells with raised borders and flat outer walls, but also a coarser mesh with lumina significantly larger than one cell. SEM allows us to use higher magnifications and describe surface details more precisely.

C. Y. Liao et al. (2013) studied the anatomy and micromorphology of the fruits of the East Asian species Angelica s. 1. and performed molecular phylogenetic analysis based on the ITS and ETS 
regions of nuclear DNA and several plastid genes. It was shown that the genus Ostericum is not related to the rest of Angelica s. 1. In terms of micromorphology, Ostericum species have large convex, rigid exocarp cells, while the rest of Angelica s. 1. have smaller cells with flat or concave outer walls, or cells that are generally indistinguishable. Within the Angelica group, micromorphology has no taxonomic significance, but it is important as a distinction from the genus Ostericum. O. huandongensis is close to A. amurensis and Czernaevia laevigata in terms of fruit micromorphology and molecular characteristics, but the authors did not propose a new nomenclature combination for it. Fig. 4 in C. Y. Liao et al. (2013) shows elongated cells on the surface of Ostericum fruits; however, we observed that most cells have an isodiametric shape (Fig. 3I, 6C; Ostroumova, 2018).

The exocarp of Aulacospermum and Pleurospermum consists of large convex cells, and the stomata are located on low bulges. The taxonomic affinities of these genera are confirmed by molecular data; both of them belong to the Pleurospermeae clade (Downie et al., 2010). Large convex cells are known in phylogenetically distant genera: Hansenia belongs to the Pleurospermopsis clade, Ostericum belongs to the Selineae clade, and Tilingia belongs to the Acronema clade. On the fruits of the studied species Hansenia, Ostericum, and Tilingia, there are no tubercles, the stomata are located on the plane of the exocarp, and stomata are extremely rare in Ostericum. The stomata on the tubercles are also known in the species of the genus Astrantia belonging to the subfamily Saniculoideae (Kljuykov et al., 2018).

W. Barthlott et al. (1998) identified 23 types of epicuticular wax. A thin waxy film is always present on the surface, but it is difficult to see it using SEM. It does not mask the sculpture of the cell wall and cuticle. The authors indicated that wax platelets are widespread in land plants and the Carrot family is not an exception. We have observed scattered platelets in several species; in the genus Bupleurum, platelets are present in almost all species and are densely arranged. We also observed smooth and rough wax crusts on the fruits of the Apiaceae.

Özcan (2002, 2004) studied 27 Bupleurum species, described them in detail and provided good illustrations. He identified several types of surfaces and compiled a key for identifying species by micromorphological characteristics. Wax crystalloids were found in almost all studied species; according to the author, their location, shape (ordinary and membranous plates, and rods), and number are important for the diagnosis of species. The author overestimates the stability of the characters: "the surface characteristics in mature fruit specimens are stable features which are not effected by environmental conditions" (Özcan, 2004, p. 72). For example, he reported that $B$. rotundifolium and $B$. lancifolium have no wax platelets, but we observed (Fig. 8E; Ostroumova, Kljuykov, 2015) densely spaced plates in some specimens, both solitary and in groups.

Y. Yaşil et al. (2018) studied 26 species of the genus Pimpinella from Turkey and identified 9 micromorphological types. Significant interspecific and intraspecific variability of the shape of the fruit and its surface, as well as the lack of correlation between these groups of characters, was noted. The results of cluster analysis based on 28 characteristics of the fruit and the general morphology of plants, generally correspond to the traditional system of the genus. Unfortunately, the authors did not mention the fine relief of the hair surface. Judging by the illustrations, the relief is tuberculate also known among many other representatives of the Pimpinelleae clade (Pimenov et al., 2021).

Bani et al. (2016) studied the fruit micromorphology of 8 species of the genus Grammociadium. A different degree of variability of characters was shown. On the one hand, all species of the subgenus Caropodium (Stapf et Wettstein) Tamamschian et Vinogradova are similar to each other in micromorphology, they belong to type 5: a longitudinally grooved surface with a striate fine relief and without visible cell boundaries; and in these characters they differ from the type subgenus. On the other hand, the two subspecies G. macrodon differ drastically from one another: ssp. nezaketiae has tubercles of various sizes on the surface and a pronounced striate, rugulate and striato-knotted (in our terminology) fine relief, while ssp. macrodon has a relatively flat surface and a weakly pronounced striate relief.

Features of fine relief are also of taxonomic importance in the genus Trinia. For example, in T. glauca, a striate and rugulate relief of cells is strongly expressed, while in the closely related species T. multicaulis, the surface is almost smooth, only along the ridges of the ribs is a striated pattern noticeable (Fedoronchuk, 1983).

Guo et al. (2017) showed that Chamaesium novemjugus is a separate species and not a synonym for $C$. spatuliferum. Among the diagnostic features, they cited a fine surface relief - striate (striate 
and rugulate in the illustrations) in Chamaesium novemjugus, in contrast to the smooth relief in the second species.

When considering the Far Eastern species, we noticed that the genus Kitagawia Pimenov differs in micromorphology from the type species of the genus Peucedanum - P. officinale (Ostroumova, 2018). In the Kitagawia species including the Siberian species $K$. baicalensis, fruits are either pubescent or have areas with rugulate cuticles. On the contrary, fruits of $P$. officinale are glabrous, the cell boundaries are indistinguishable, and the fine surface relief is striate. The Siberian species Peucedanum morisonii belongs to the closest relationship of $P$. officinale; it also has indistinguishable cell boundaries on the surface of the fruit and a striate cuticle; a significant part of the surface is covered with wax. The same surface was revealed in $P$. guvenianum, which was recently described in Turkey (Yildiri, Duman, 2017). Other Siberian genera, which were previously included in Peucedanum s. 1., have a peculiar surface sculpture and a small amount of wax. Haloselinum falcaria has cell groups with sunken borders, flat outer walls, striate and rugulate cuticles, and small blunt projections. In Thysselinum palustre, the cell boundaries are indistinguishable, the cuticle is striate and sometimes rugulate. In Xanthoselinum alsaticum, cells are visible in some areas, and there are small sharp and obtuse projections with a striatoknotted cuticle; on the rest of the surface, the fine relief is striate and densely rugulate.

We have already noted that on the fruits of Pachypleurum alpinum, Phlojodicarpus villosus, Seseli condensatum, Seseli ledebourii, S. libanotis, and Stenocoelium athamantoides, there is a whole spectrum of hairs, from small sharp projections to the usual hairs $50-100 \mu \mathrm{m}$ in length. It is probable that, as the fruit grows, new hairs develop on it at different times. The same picture is observed on the fruits of many European Seseli species: S. tortuosum L., S. arenarium M. Bieb., S. rigidum Waldstein et Kitaibel, Seseli besserianum Stoyanov et Ostr., S. dichotomum (Boiss.) Manden., S. gummiferum Pall. ex Smith., S. lehmannii Degen, and also S. eriocephalum (Pall. ex Spreng.) Schisck. from Kazakhstan and the Orenburg Region of Russia (Kljuykov et al., 2018; Stoyanov et al., 2020).

Species with secondary ribs have hairs on the primary ribs. Caucalis has multicellular setae on the primary ribs, with a long apical cell that has a tuberculate surface. In this species, the apices of the hooks on the secondary ribs are slightly rugulate. Daucus carota has smooth, anchor-like glochidia on the secondary ribs and tuberculate hairs with pedestals on the primary ribs (Fig. 9G). The fruits of Turgenia latifolia are covered with glochidia of various sizes, and there are single and tufted hairs with a rugulate or tuberculate surface on the primary ribs.

Klimko (2013a, b) reported that young fruits of Heracleum sphondylium ssp. sphondylium are more pubescent than mature ones. Different specimens of this subspecies have either long, thin-walled, nonmineralized hairs with a smooth surface (ribbonlike), or short subulate, mineralized hairs with a tuberculate surface. The variety with subulate hairs is widespread in Poland. Ssp. sibiricum usually produces glabrous fruits, but the subulate variety is rarely found. According to our observations (Ostroumova, 2018), a closely related species H. dissectum also has densely pubescent ovaries and slightly pubescent fruits. Heracleum sibiricum in Russia has glabrous fruits, and rarely, SEM reveals ribbon-like and subulate hairs.

Like other groups of characters, micromorphology does not always provide data interesting for taxonomy. For example, a glabrous surface with indistinguishable cell boundaries and, in addition, covered with a layer of wax, carries little information. To find traits useful for distinguishing between species and clarifying their relationships, it is necessary to study and compare a large amount of material in order to identify traits most stable in a given group of plants.

Unique characters that characterize one taxon and are absent in other species of the family are very rare in the Apiaceae. Among positive examples, we can name the secondary ribs of the mericarps, which are known only in two subtribes of the tribe Scandiceae; T-shaped hairs found in only one subclade of the tribe Pimpinelleae (Pimenov et al., 2019); dome-shaped projections arranged in regular rows in the genera Anthriscus, Geocaryum, Kozlovia, Krasnovia, Neoconopodium, and Scandix in the subtribe of Scandicinae (Engstrand, 1973; Spalik, 1997; Spalik, Downie, 2001; Ostroumova, 2018).

Much more often, similar structures develop on the fruits of taxonomically distant genera. For example, hooked spines are known in Caucalis and Orlaya Hoffm. from the tribe Caucalideae, in Bupleurum sintenisii Asch. et Urb. ex Huter (peculiar tribe Bupleureae), and many Sanicula species belonging to another subfamily, the Saniculoideae. The hairs on "pedestals" are known in the genera Anthriscus, Heracleum, Laserpitium 
L., Myrrhys Mill., Pimpinella, Stenocoelium, and Torilis, belonging to different tribes of the family. Large convex exocarp cells are found in the species Aulacospermum, Elaeosticta Fenzl, Halosciastrum Koidz., Hansenia, Ligusticum L., Ostericum, Pleurospermum, and Taeniopetalum Vis., which cannot be considered related. Wax platelets were found in genera Bupleurum, Aegopodium, Angelica, Ferula, Pimpinella, Sanicula, and Trinia; and, in general, they are widespread in terrestrial plants (Barhtlott et al., 1998).

We have already considered (Ostroumova, 2019) the distribution of anatomical characters in the Apioideae subfamily according to the tribes of the Drude system (1897-1898) based on morphology and according to the clades of the molecular tree (Downie et al., 2010). The analysis of the distribution of stomata types, the vascular system of the petiole, the shape of the endosperm, large rib secretory ducts in fruits, and small cyclic ducts was carried out. In all subdivisions, parallel series of variability of several characters are observed. These phenomena have been known for a long time, and they are explained within the framework of the law of homological series of N. I. Vavilov (1922).

The parallel appearance and disappearance of traits in different groups of organisms (in other words, homaplasy) is called also the manifestation of "silent" genes (Kubizki et al., 1991), as well as the "Brownian motion" (Endress, Matthews, 2012) or "trait development potential" by Rajakumar et al. (2012).

The genotype of a single plant may contain mechanisms for the development of different morphological structures. For example, among the somaclones obtained from one individual Onobrychis arenaria (Kit.) DC., individuals with taxonomic characters $O$. viciifolia Scop., $O$. transcaucasica Grossh., and O. sibirica Turcz. ex Bess. were revealed (Rozhanskaya et al., 2016).

The study of the complete genomes of Petunia inflata and $P$. axillaris made it possible to trace the details of the evolution of flower color (Bombarely et al., 2016). P. inflata has purple flowers and is pollinated by bees, while the flowers of $P$. axillaris are white, and the plant is pollinated by night moths. Both species have the set of functional genes for the synthesis of anthocyanins. In P. axillaris, MYB factor AN2, which regulates the synthesis of anthocyanins in petals, was inactive. Significant changes in petal color have been associated with small changes in genotype.

Irrespectively of the mechanisms that govern the morphological diversity, the widespread parallelism and mosaic distribution of characters complicate the taxonomy of the Apiaceae. The use of morphological and molecular methods has not yet made it possible to create a satisfactory family system. Further comprehensive study of the family is required.

\section{Acknowledgements}

This work is supported by the Russian Foundation for Basic Research (grant No 19-04-00370). I am grateful to the curators of AA, ALTB, IRC, KUZ, LE, MHA, MW, TK, and VILR herbaria for use of their facilities. SEM studies are performed at the User Facilities Center of M. V. Lomonosov Moscow State University under financial support of Ministry of Education and Science of Russian Federation and using Joint Usage Center "Instrumental methods in ecology" at the A. N. Severtsov Institute of Ecology and Evolution RAS. I thank the anonymous reviewer for a detailed discussion of my work and stimulating criticism.

\section{REFERENCES}

Bani B., Karakaya M. A., Çeter T. 2016. Fruit micromorphological characters of the genus Grammosciadium DC. (Apiaceae) in Turkey. Phytotaxa 246(2): 184-191. DOI: 10.11646/phytotaxa.246.3.2

Barthlott W. 1981. Epidermal and seed surface characters of plants: systematic applicability and some evolutionary aspects. Nordic Journal of Botany 1(3): 345-355.

Barthlott, W., Ehler N. 1977. Raster-Elektronenmikroskopie der Epidermisoberflächen von Spermatophyten. Tropische und subtropische Pflanzenwelt 19: 367-467.

Barthlott W., Neinhuis C., Cutler D., Ditsch F., Meusel I., Theisen I., Wilhelmi H. 1998. Classification and terminology of plant epicuticular waxes. Botanical Joumal of the Linnean Society 126: 237-260.

Bombarely A., Moser M., Amrad A., Bao M., Bapaume L., Barry C. S., Blie M., Boersma M. R., Borghi L., Bruggmann R., Bucher M., D'Agostino N., Davies K., Druege U., Dudareva N., Egea-Cortines M., Delledonne M., Fernandez-Pozo N., Franken P., Grandont L., Heslop-Harrison J. S., Hintzsche J., Johns M., Koes R., Lv X., Lyons E., Malla D., Martinoia E., Mattson N. S., Morel P., Lukas A. Mueller L. A., Muhlemann J., Nouri E., Passeri V., Pezzotti M., Qi Q., Reinhardt D., Rich M., Richert-Pöggeler K. R., Robbins T. P., Schatz M. C., Schranz M. E., Schuurink R. C., Schwarzacher T., Kees Spelt K., Tang H., Urbanus S. L., Vandenbussche M., Vijverberg K., 
Villarino G. H., Warner R. M., Weiss J., Yue Z., Zethof J., Quattrocchio F., Sims T. L., Kuhlemeier C. 2016. Insight into the evolution of the Solanaceae from the parental genomes of Petunia hybrida. Nature Plants, 27 May 2016 , Article number 16074. DOI: 10.1038/NPLANTS.2016.74

Downie S. R., Spalik K., Katz-Downie D. S., Reduron J-P. 2010. Major clades within Apiaceae subfamily Apioideae as inferred by phylogenetic analysis of nrDNA ITS sequences. Plant Diversity and Evolution 126, 1-2: 111-136.

Drude O. 1897-1898. Umbelliferae. In: Die natürlichen Pflanzenfamilien. A. Engler, K. Prantl (eds). B. 3, H. 8. Leipzig: Wilhelm Engelmann. Pp. 63-250.

Duran A., Behçet L., Öztürk M. 2015. Diplotaenia bingolensis (Apiaceae), new species from east Anatolia, Turkey. Plant Systematics and Evolution 301: 467-478. DOI 10.1007/s00606-014-1086-9

Endress P. K., Matthews M. L. 2012. Progress and problems in the assessment of flower morphology in higherlevel systematics. Plant Syst. Evol. 298: 257-276. DOI: 10.1007/s00606-011-0576-2

Engstrand L. 1973. Generic delimitation of Bunium, Conopodium and Geocaryum (Umbelliferae). Bot. Notiser 126: 146-154.

Fedoronchuk N. M. 1983. Systematica, geografiya i filogeniya rodov Trinia, Rumia I Ledebouriella [Systematics, geography and evolution of the genera Trinia, Rumia and Ledebouriella]. Kiev: Naukova dumka. 160 pp. [In Russian] (Федорончук Н. М. Систематика, география и филогения родов Trinia, Rumia и Ledebouriella. Киев: Наукова думка, 1983. 160 с.).

Guo X.-L., Tan J.-B., Ни H.-Y., Yи Н.-X., Не X.-J. 2017. Morphological and micromorphological data support the independent specific status of Chamaesium spatuliferum (Apioideae, Apiaceae) from China. Phytotaxa 314(1): 081-088. DOI: 10.11646/phytotaxa.314.1.6

Hesse M., Halbritter H., Zetter R., Weber M., Buchner R., Frosch-Radivo A., Ulrich S. 2009. Pollen terminology. An illustrated handbook. Wien, N. Y. 259 pp.

Klimko M., Truchan M., Wysakodska I. 2013a. Micromorphological studies on Heracleum L. (Apiaceae) in Poland with emphasis on ovary ornamentations and trichomes. Roczniki Akademii Rolniczej w Poznaniu. CCCXCII: 5-12.

Klimko M., Truchan M., Wysakodska I. 2013b. Fruit and seed morphology of the genus Heracleum L. (Apiaceae) in Poland. Roczniki Akademii Rolniczej w Poznaniu. CCCXCII: 13-25.

Kljuykov E. V., Ostroumova T. A., Zakharova E. A., Ukrainskaja U. U. 2016. Umbelliferae of the Kemerovo Region: list of species, nomenclature, and carpological atlas. Botanicheskiye issledovaniya Sibiri i Kazakhstana [Botanical research in Siberia and Kazakhstan] 22: 16-34. [In Russian] (Клюйков Е. В., Остроумова Т. А., Захарова $\boldsymbol{E}$. A., Украинская У. A. Зонтичные Кемеровской области: список видов, номенклатура и карпологический атлас // Ботанические исследования Сибири и Казахстана, 2016. Вып. 22. С. 16-34).

Kljuykov E. V., Ostroumova T. A., Zakharova E. A., Ukrainskaya U. A., Petrova S. E. 2018. Atlas plodov zontichnykh Yevropeyskoy chasti Rossii [Atlas of fruits of the Umbelliferae in the European part of Russia]. Moscow: Botanical Garden of MSU. 191 pp. [In Russian] (Клюйков Е. В., Остроумова Т. А., Захарова Е. А., Украинская У. А., Петрова $\boldsymbol{C}$. E. Атлас плодов зонтичных Европейской части России. М.: Ботанический сад МГУ, 2018.191 с.).

Kubitzki K., von Sengbusch P., Poppendieck H. 1991. Parallelism, its evolutionary origin and systematic significance. Aliso 13(1): 191-206.

Liao C., Downie S. R., Li Q., Yu Y., He X., Zhou B. 2013. New insights into the phylogeny of Angelica and its allies (Apiaceae) with emphasis on East Asian species, inferred from nrDNA, cpDNA, and morphological evidence. Systematic Botany 38(1): 266-281. DOI: 10.1600/036364413X662060

Murley M. R. 1951. Seeds of the Cruciferae of Northeastern North America. American Midland Naturalist 46: $1-81$

Ostroumova T.A. 2018. Fruit micromorphology in the Umbelliferae of the Russian Far East. Botanica Pacifica. A journal of plant science and conservation 7 (1): 41-49. DOI: 10.17581/bp.2018.07107

Ostroumova T. A. 2019. Anatomical characters of fruit and leaf in the family Umbelliferae, subfamily Apioideae, and their evolution. In: Plant anatomy: traditions and perspectives: Materials of the international Symposium dedicated to the 90th anniversary of Prof. Ludmila Ivanovna Lotova (September 16-22, Moscow). Vol. 1. Moscow: MaksPress. Pp. 203-207.

Ostroumova T. A. 2020. Fruit micromorphology in the Umbelliferae in Siberia and patterns of morphological diversity in the family. Problems of Botany of South Siberia and Mongolia 19, 1: 44-48. [In Russian] (Ocmpoyмoвa T. $\boldsymbol{A}$. 2020 Микроморфология плодов зонтичных (Umbelliferae) Сибири и особенности морфологического разнообразия этого семейства. Проблемы ботаники Южной Сибири и Монголии, 2020. Т. 19, № 1. C. 44-48. DOI: 10.14258/pbssm.2020009

Ostroumova, T. A., Kljuykov E. V. 2015. Fruit structure and microsculpture in the annual species of the genus Bupleurum, section Perfoliata (Umbelliferae). Phytologia Balcanica 21(2): 117-127.

Ostroumova, T. A., Pimenov M. G., Ukrainskaya U. A. 2010. Micromorphological diversity of hairs and emergences on fruits in the Umbelliferae and its taxonomic value. Bot. Zhurn. 95(9): 1219-1231. [In Russian] (Ocmpoymo- 
ва Т. А., Пименов М. Г., Украинская У. А. Разнообразие микроморфологии волосков и эмергенцев на плодах зонтичных (Umbelliferae) и его таксономическое значение // Бот. журн., 2010. Т. 95, № 9. С. 1219-1231).

Ostroumova, T. A., Pimenov M. G., Ukrainskaya U. A., Tilney P. M. 2011. Fruit micromorphology in the Umbelliferae and its taxonomical significance. In: XVIII International Botanical Congress (Melbourne, Australia, 23-30 July 2011). Abstract book. Melbourne. Pp. 562-563.

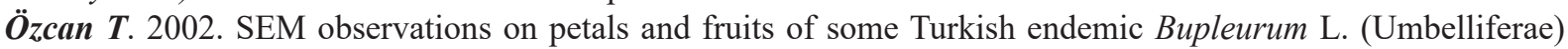
species. Botanical Journal of the Linnean Society 138: 441-449. DOI: 10.1046/j.1095-8339.2002.00018.x

Özan T. 2004. Analysis of the fruit surfaces in Bupleurum L. (Umbelliferae) with SEM. Plant Syst. Evol. 247: 61-74. DOI: 10.1007/s00606-004-0135-1

Pimenov M., Degtjareva G., Ostroumova T., Samigullin T., Zakharova E. 2019. What is Seseli diffusum? A comparative morphological and molecular appraisal of a critical species of the Umbelliferae. Plant Systematics and Evolution 305: 49-59. DOI: 10.1007/s00606-018-1550-z

Pimenov M., Degtjareva G., Ostroumova T., Samigullin T., Zakharova E. 2021. Polyphyletic Trachyspermum (Umbelliferae) revisited: a contribution of molecular and carpological data. Plant Biosystems - An International Journal Dealing with all Aspects of Plant Biology. DOI: 10.1080/11263504.2021.1918781

Pimenov M. G., Ostroumova T. A. 2012. Umbelliferae of Russia. Moscow: KMK Scientific Press. 477 pp. [In Russian] (Пименов М. Г., Остроумова Т. А. 2012. Зонтичные (Umbelliferae) России. М.: Изд-во КМК. 477 с.).

Plunkett, G. M., Pimenov M. G., Reduron J.-P., Kljuykov E. V., van Wyk B.-E., Ostroumova T. A., Henwood M. J., Tilney P. M., Spalik K., Watson M. F., Lee B.-Y., Pu F.-D., Webb C. J., Hart J. M., Mitchell A. D., Muckensturm B. 2019. Apiaceae. In: Families and Genera of Vascular Plants. K. Kubizky, J. W. Kadereit, V. Bittrich (eds). Vol. 15. Cham: Springer International Publishing AG. Pp. 9-206.

Rajakumar R., Mauro D. S., Dijkstra M. B., Huang M. H., Wheeler D. E., Hiou-Tim F., Khila A., Cournoyea M., Abouheif E. 2012. Ancestral developmental potential facilitates parallel evolution in ants. Science 335(6): 79-82. DOI: $10.1126 /$ science. 1211451

Rozhanskaya O. A., Shilova T. V., Gorshkova E. M. 2016. Variability of taxonomic characteristics in populations of regenerated plants and generative progenies of Onobrychis arenaria (Kit.) DC. In: Problems of Botany of South Siberia and Mongolia. Proceedings of the 15th International Scientific and Practical Conference (Barnaul, 23-26 May 2016). Barnaul. Pp. 321-324. [In Russian] (Рожанская О. А., Шилова Т. В., Горшкова Е. М. Изменчивость таксономических признаков в популяциях растений-регенерантов и генеративных потомств эспарцета песчаного (Onobrychis arenaria (Kit.) DC.) // Проблемы ботаники Южной Сибири и Монголии: Сб. ст. по материалам XV Междунар. науч.-практ. конф. (г. Барнаул, 23-26 мая 2016 г.) Барнаул, 2016. С. 321-324).

Seregin A. P. (Ed.). 2021. Moscow Digital Herbarium: Electronic resource. Moscow: Moscow State University. URL: https://plant.depo.msu.ru/ (Accessed 21.05.2021).

Spalik K. 1997. Revision of Anthriscus (Apiaceae). Polish Bot. Stud. 13: 1-69.

Spalik K., Downie S. R. 2001. The utility of morphological characters for inferring phylogeny in Scandiceae subtribe Scandicinae (Apiaceae). Ann. Missouri Bot. Garden 88: 270-301.

Stearn W. T. 1983. Botanical Latin. 3d edition. David and Charles Publishers, Newton Abbot London. 565 pp.

Stoyanov S., Ostroumova T., Degtjareva G., Samigullin T. 2020. Seseli besserianum (Apiaceae), a restored species and a replacement name for Seseli peucedanifolium Besser. Phytotaxa 458(2): 120-138 DOI: 10.11646/phytotaxa.458.2.1

Thiers B. 2008+ [continuously updated]. Index Herbariorum: A global directory of public herbaria and associated staff. New York Botanical Garden's Virtual Herbarium. URL: http://sweetgum.nybg.org/science/ih (Accessed 21.05.2021).

Vavilov N.I. 1922. The law of homologous series in variation. J. Genet. 12: 47-89.

Wang Huan-Chong, Zhou Xin-Mao, Sun Hang, Wang Yue-Hua. 2013. Acronema crassifolium sp. nov. (Apiaceae), a distinct new species from Yunnan, southwest China. Phytotaxa 87 (3): 39-44. DOI: 10.11646/phytotaxa.87.3.1

Yeşil Y., Akalın E., Akpulat A., Vural C. 2018. Fruit morphology of the genus Pimpinella (Apiaceae) in Turkey. Anales del Jardín Botánico de Madrid 75 (2): e072. DOI: 10.3989/ajbm.2509

Yildiri H., Duman H. 2017. Peucedanum guvenianum (Apiaceae), a new species from West Anatolia, Turkey. Turkish Journal of Botany 41: 600-608. DOI: 10.3906/bot-1701-56 